\title{
1 Transcriptomic Insights into the Responses in Leaves Storing 2 Lipid Organelles under Different Irradiances
}

3 Authors:

4 Somrutai Winichayakul, ${ }^{\bowtie, a}$ Richard Macknight, ${ }^{\text {b }}$ Zac Beechey-Gradwell, ${ }^{a}$ Robyn Lee, ${ }^{b}$

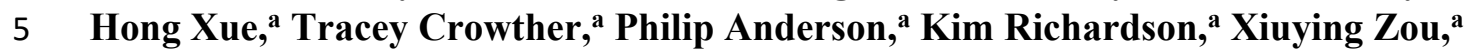

6 Dorothy Maher, ${ }^{\text {a Shona Brock, }},{ }^{\mathrm{a}}$ Luke Cooney, ${ }^{\mathrm{a}}{ }^{\text {Gregory Bryan, }},{ }^{\mathrm{a}}$ and Nick Roberts ${ }^{\mathrm{a}}$

8 Affiliations:

9 a Resilient Agriculture, AgResearch Ltd., Tennent Drive, Palmerston North 4442, New

10 Zealand

One sentence summary: analysis. K.R., X.Z. and D.M. generated transgenic ryegrass, screening, and selection. S.B. determined percentage of carbon and nitrogen. S.W. performed immunoblotting of cysteine oleosin. H.X. determined water soluble carbohydrate. L.C. performed IRGA and analysed leaf photosynthetic parameters. T.C. and P.A. performed lipid analysis. S.W. and P.A. determined leaf chlorophyll concentration. R.M. and R.L. performed RNA preparation, sequencing, and transcriptomic analysis. N.R. and S.W designed the project and wrote the manuscript. R.M. reviewed the manuscript. N.R. and G.B. conceived the project and supervised the research. 


\section{ABSTRACT}

40

To increase the nutritional value of forage, transgenic ryegrass known as $\underline{\text { High }}$ Metabolizable Energy (HME) were previously generated that co-express cysteine-oleosin and diacylglycerol O-acyltransferase. HME not only accumulate lipids in the leaf but also has elevated $\mathrm{CO}_{2}$ assimilation and increased biomass. Shading is one of the most influencing factors for ryegrass growth environments particularly in swards. The aim of this study, therefore, was to determine the influence of irradiance levels on photosynthesis and gene expression in the HME leaves when compared with their corresponding non-transformant (NT). Under low light (150-250 $\left.\mu \mathrm{mol} \mathrm{m}^{-2} \mathrm{~s}^{-1}\right)$ and standard light (600-1000 $\left.\mu \mathrm{mol} \mathrm{m}^{-2} \mathrm{~s}^{-1}\right)$, the HME accumulated more lipid than NT. The previously reported elevated photosynthesis and increased biomass was observed when the HME were grown under standard light but not under low light. Under both light conditions, compared to NT, the HME had upregulated a number of transcripts involved in lipid metabolism, light capturing, photosynthesis, and sugar signalling network while downregulated genes participated in sugar and fructan biosynthesis. We further discuss how the HME differentially manipulated several genes other metabolic pathways including maintenance of redox homeostasis. Combined, the data suggests that the increased photosynthesis capacity in the HME likely corresponds to an increase of microlipid sink strength; these are influenced by available light energy and may be related to diffusional and biochemical activities of stomata. Overall, this work provides a clearly understanding of the changes in molecular and biochemical mechanisms underlying the carbon storing as leaf lipid sink of the HME ryegrass. 


\section{INTRODUCTION}

The climate crises and increasing world population means dramatic increases in the production of food, forage and renewable fuels is needed using the existing agricultural land. To address this, we and others have been exploring biotechnological approaches to increase the levels of energy-rich triacylglycerol (TAG) content in plant non-seed tissues $(\mathrm{Xu}$ and Shanklin 2016; Vanhercke et al., 2019, and references therein). Increased TAG synthesis in vegetative tissues can be achieved by promoting the carbon flux into fatty acid (FA) and TAG synthesis through the manipulation of enzymes and/or transcriptional regulators whilst suppressing FA catabolism, including FA utilization and TAG turnover. Co-expression of diacylglycerol O-acyltransferase (DGAT, the enzyme for TAG biosynthesis) and WRINKLED1 (WRI1, a key regulator of lipid homeostasis in the leaves) in a sugardependent TAG lipase $(s d p 1)$ mutant of tobacco yielded 5-8\% dry weight (DW) TAG accumulation; however these plants incurred a growth penalty (Kelly et al., 2013). Other approaches include using a double mutant of sdpl and trigalactosyldiacylglycerol 1-1 in Arabidopsis resulting in approximately $8 \%$ leaf TAG $(\% \mathrm{DW})$ while co-expressing DGAT1, WRI1, OLEOSIN and the lipid-related transcription factor LEAFY COTYLEDON 2 in tobacco leaves resulted to $23-30 \%$ TAG accumulation (Fan et al., 2014; Vanhercke et al., 2017, respectively). The tobacco plants also had a reduced biomass however; although this was reported to be partially offset by manipulating genes involved in carbohydrate metabolism (Mitchell et al., 2020). We previously reported that the development of transgenic lines of ryegrass (Lolium perenne) and Arabidopsis, known as high metabolizable energy (HME) plants, that co-express DGAT and cysteine-oleosin (cys-OLE, a modified oleosin designed to protect lipid droplets from proteolysis). These plants have up to twice the FA content in mature leaves (from $\sim 3.5 \%$ to $\sim 7 \% \mathrm{DW}$ ) as well as increasing plant $\mathrm{CO}_{2}$ assimilation rate and biomass (Roberts et al., 2010 \& 2011; Winichayakul et al 2013 \& 2020; Beechey-Gradwell et al., 2018 \& 2020; Cooney et al., 2021). We speculated the trade-off between TAG and sugars in HME ryegrass leaves alters the leaf sugar homeostasis which in turn mitigates negative feedback on photosynthesis (Beechey-Gradwell et al., 2020; Cooney et al., 2021). However, we observed that HME ryegrass with leaf FA contents above $6.8 \%$ DW (TAG $>2.5 \% \mathrm{DW}$ ) appears to have adverse effect on the growth when compared to nontransformant (NT). Understanding the molecular and biochemical changes during TAG accumulation in the non-seed tissues may help to explain these results. 
102

103

104

105

106

107

108
The de novo biosynthesis of FA and TAG synthesis places high demands for both energy and reductants which is provided by sugars and the sugars themselves also have multiple roles in signalling pathways including sink regulation of photosynthesis (Xu and Shanklin, 2016; Paul and Foyer, 2001, and references therein). Regulation of photosynthesis requires a communication between sugar sensing and redox chemistry; these can be orchestrated in response to changing environments (Queval and Foyer 2012). Of the environmental factors, light has a substantial effect on photosynthesis over the period of the day. Low light density directly influences photosynthesis and photomorphogenesis, which in turn impacts on the agronomic traits of plants. Reduction of biomass production and higher membrane lipid peroxidation are two common plant responses to adverse low light, especially during winter when this is combined with low temperatures (Gaba and Black, 1983; Höglind et al., 2011). Low irradiance causes limitations of photosynthesis by inhibiting photosynthetic efficiency by lowering levels of PSII, Rubisco, electron transportation rate, and $\mathrm{CO}_{2}$ assimilation (Leong and Anderson, 1984). To enhance the tolerance to low lighting, plants improve expression of some specific genes and proteins such as spermidine synthase, ATP synthase $\beta$ subunit, and Rubisco activase ( $\mathrm{Lu}$ et al., 2019, and references therein). It is important to understand how the HME ryegrass perform and acclimate to lower light environment such as those experience under sward (low light field canopy) conditions (Faurie et al., 1996). Does shading affect FA and TAG accumulation in HME leaves? Does elevated photosynthesis and greater biomass created in the HME due to micro-lipid sink overwhelm shading reduced photosynthetic capacity? In this study, therefore, the performance of HME ryegrass grown under a low light density $\left(150-250 \mu \mathrm{mol} \mathrm{m} \mathrm{m}^{-2} \mathrm{~s}^{-1}\right)$, was compared to plants grown under standard lighting (600-1000 $\left.\mu \mathrm{mol} \mathrm{m} \mathrm{m}^{-2} \mathrm{~s}^{-1}\right)$. FA, sugars, growth, photosynthetic parameters and transcriptomic analysis provided evidences into mechanisms fundamental stable lipid storage, sink strength and photosynthesis. 
128

129

\section{RESULTS}

\section{Leaf and Sheath FA and Water-Soluble Carbohydrate Levels are Altered in HME Ryegrass and Influenced by Light Levels}

Previously generated multiple independent HME lines (HMEs) that co-express DGAT and cys-OLE were screened for their lipid accumulation in the leaf. In this study we selected three of the HMEs (HME30, HME34, and HME42) because these lines represented a range of leaf lipid profiles and total leaf lipid content. Plants (including NT) were grown to undertake a detailed examination of the influence of different photosynthetic irradiance levels on lipid content, growth, photosynthesis and gene expression in the leaves.

Leaf FA profiles of the three HMEs were altered significantly as genotype $\mathrm{x}$ light treatment interactions. This included an increase in the proportions of 18:1 and decreases in 16:0, 16:1, and 18:3 (Figure 1). HMEs also have increased proportions of 18:2; 20:0, and 20:1 but these proportions were not affected by the low light treatment. Furthermore, 22:1 was detected in HMEs but not in NT; the level increased in low light. Between the HMEs, HME34 had slightly higher proportions of leaf 18:0, and 22:1. There were small differences in the leaf FA profiles of NT grown in standard compared to low irradiance; this included increases in the proportions of 16:0,18:1, 18:2 and decreases in 16:1, and 20:1. Ryegrass sheaths are the lower part of subtending leaves, forming a pseudostem, have different FA profile and content to that of the leaf. Compared to NT the sheath FA profiles of HMEs under standard light showed increases in 18:1, 18:2, 20:0, and 22:1 and decreases in 16:0, 16:1, 18:3, and 20:1; while only 16:0, 16:1 and 22:1 were affected in low light. The FA profile of the HME34 sheath was different to the other two HMEs in the proportions of 16:0 and 20:1 under the low light treatment. There were only small changes of 16:0, 18:2 in sheath FA of NT in response to low light treatment.

Table 1 shows FA levels for leaves and sheaths harvested at 21 days of regrowth. FA levels accumulated to a higher content in the leaves than in the sheath in all genotypes and under both light treatments. Compared to NT, all three HMEs had significantly elevated leaf FA $(\sim 55-75 \%)$ and sheath FA $(\sim 29-72 \%)$ in both light conditions $(P<0.001)$. Low light significantly increased the leaf FA in both NT and HMEs but in sheath only HMEs significantly increased FA. The line with the highest accumulation of leaf lipids (HME34) also had the highest accumulation of cys-OLE in both light conditions (Table 1 and Supplementary Figure S1).

Both leaf and sheath sugar concentrations decreased significantly when the plants were grown under low light $(P<0.001)$ (Table 1); the decrease was greatest in the high molecular 
weight (HMW) fraction. HMW-sugars (primarily fructans) accumulated to a higher concentration in the sheath than in the mature leaves; the opposite was true for the low molecular weight (LMW) sugar fraction. All plants had lower levels of leaf and sheath HMW-sugars under low light. HMW-sugars were significantly lower in the leaves of two HMEs (HME34 and HME42) than the NT under standard lighting, however statistical analysis showed no significant difference of leaf and sheath HMW-sugars between genotypes under low light conditions. In both light conditions, HME leaf and sheath LMW-sugars were lower than NT $(P<0.001)$.

\section{Effect of Low Light on the Growth of HME Ryegrass}

All relative growth rates (RGR) of plants grown under standard lighting were significantly greater than plants grown under low light (Figure 2). When comparing plants grown under standard light the overall plant RGR was significantly greater in all HMEs compared to the NT; in descending order the main organs contributing to the elevated RGR were roots, leaves, sheath (Figure 2). In contrast, there was no significant difference in the overall RGR of any line when the plants were grown under low light; this was reflected by the large drop of elevated root RGR trend under this condition.

Plants adapt to low light conditions by increasing both leaf area and chlorophyll content in an attempt to capture as much light as possible. In this study we found no significant differences in specific leaf area (SLA) between the HME lines and NT whereas leaves formed under low light having on almost twice the SLA (164-179\%) in comparison with standard light leaves (Table 2). Associated with this is an elevation of the shoot to root ratio $(\mathrm{L} / \mathrm{R})$ and leaf water content as well as decreases of leaf carbon content (per unit dry matter) and leaf nitrogen content (per unit area, $\mathrm{N}_{\text {areaa }}$ ). There were significant differences in each of these parameters when comparing all plants grown under two different levels of irradiance (Table 2). When comparing between plants grown under low light however, only the leaf carbon content showed a significant difference, where the NT was lower than all HMEs. In comparison, under standard lighting there were significant differences between the HMEs and NT in all these parameters except the leaf nitrogen content. More specifically, under standard light the HMEs have reduced L/R, increased leaf carbon, water and chlorophyll contents. The higher leaf water contents of the HMEs under standard light compared to NT suggest that photosynthesis per unit of water (water use efficiency) in the HMEs may be more efficient; however, it could also reflect the greater ability of the comparatively lower $\mathrm{L} / \mathrm{R}$ enables them to keep the leaves more turgid. In standard lighting, although three HMEs 
had higher chlorophyll content (DW basis) than the NT, only one line (HME42) showed significantly higher chlorophyll content per unit leaf area. Under low light, all HMEs and NT exhibited a significant increase in chl per DW, compared to those plants grown under standard light. However, no significant difference in chl was identified between HME and NT at this irradiance. It should be noted however, the influence of light was the opposite when determining the levels of chlorophyll content per unit leaf area.

\section{Elevated Photosynthesis in HME Ryegrass Does Not Occur in Low Light}

In agreement with our previous observations (Beechy-Gradwell et al., 2018 \& 2020), under standard lighting and compared to NT, the HMEs had elevated $\mathrm{CO}_{2}$ assimilation rates (A), transpiration rates $(\mathrm{E})$, stomatal conductance $\left(g_{s}\right)$, electron transportation rates $(J)$ and quantum efficiency of photosystem II ( $\$ \mathrm{PS} 2)$ (Table 3). However, under low light there were no significant differences in any of these parameters between the HMEs and NT. In all plants the low light treatment significantly reduced A, E, $g_{s}$, and $J(55-62 \%, 49-57 \%, 47-57 \%$, and $62-64 \%$ respectively) while enhancing the $\phi_{\mathrm{PS} 2}$ (126-134\%) for light harvesting (Table 3). Differences in the response between the A of plants grown in both light densities are associated with a difference in SLA which is a growth measurement that eventually has an effect on photosynthesis.

\section{NT and HME Ryegrass RNA-Seq Analysis Under Standard Light}

To gain insights into the metabolic process differing between NT and HME ryegrass, we combined RNA sequencing with differential expression analysis. RNA samples were extracted from NT and two HMEs (HME34 and HME42) then processed to determine for differentially expressed genes. Two-well established statistical analysis methods (DESeq and Biostrings) were employed to compare the expression levels. In total 93 up- and downregulated genes were annotated in this study, calculated as the $\log _{2}$ fold-change for the identified genes ranging from \pm 1 to \pm 14 , and are presented as a heatmap (Figure 3). Within the heatmap we have grouped the genes into related biological processes including: lipid metabolism; light capture and photosynthesis; carbohydrates and the citric acid cycle; sugar signalling and redox maintenance; and nitrogen metabolism and plant and growth development. Each grouping is described in more detail below.

\section{Lipid metabolism}

As expected, the recombinant $c y s-O L E$ and $D G A T$ transcripts were detected at relatively very high levels in HME leaves and were not detected in NT. The native genes involved in lipid metabolism that were differentially regulated in HMEs compared to NT were all 
upregulated; this included genes involved in de novo FA synthesis, FA desaturation and elongation, glycerolipid synthesis, TAG catabolism, phospholipid hydrolysis and peroxisomal $\beta$-oxidation.

\section{Carbohydrates and Citric Acid Cycle}

Genes involved in carbohydrate metabolism and the citric acid cycle were both up and down regulated in HMEs compared to NT. Those that were upregulated are involved in glycolysis, the TCA cycle, gluconeogenesis and degradation of carbohydrates in the cytoplasm, as well as hydrolysis of sucrose and starch synthesis in the chloroplast. While those that were downregulated are involved in glycolysis, sucrose and fructan synthesis (Figure 3).

\section{Light Harvesting and Photosynthesis}

Like the lipid metabolism genes, all genes involved in photosynthesis (with the exception of chloroplastic chlorophyllase which is involved in chlorophyll breakdown) that we identified as being differentially expressed in HMEs were upregulated compared to NT. This included genes directly involved in light harvesting, the photosynthetic electron transport chain and the Calvin cycle (Figure 3). Other genes indirectly influencing photosynthesis by regulating gas, water and solute transport were also upregulated in HMEs.

\section{Sugar Signalling Network and Redox Potential}

The majority of differentially related genes involved in hexokinase and the sucrose nonfermenting 1-related protein kinase/trehalose 6-phosphate (SnRK1/T6P) signalling pathways were upregulated in HMEs, however, one specific bidirectional sugar transporter was down regulated (Figure 3). Similarly, the differentially expressed genes involved in redox potential were mostly upregulated in HMEs compared to NT. Notable exceptions were L-ascorbate oxidase and several aquaporin plasma membrane intrinsic proteins (PIPs).

\section{Nitrogen Metabolism and Plant Growth and Development}

Two important components of nitrogen assimilation pathway were repressed in HMEs, while two genes involved in gibberellin biosynthesis and brassinosteroid signalling pathways were upregulated (Figure 3).

\section{Differential Gene Transcriptions in HME Ryegrass to NT in Response to Low Irradiance}

In addition to the results shown in Figure 3, Figure 4 shows the normalized transcripts that were influenced by modifying the photon flux in two HMEs (HME34 and HME42) and NT. 
260 Although the cys-OLE (under the control of $C A B$ promoter) was the most abundant transcript

261 we detected under both light treatments its level increased significantly in both HMEs in 262 response to low light (Figure 4A); this agrees with the increased levels of the protein (Table 263 1). In comparison the T. majus DGAT1 transcript was only significant different $(P<0.001)$ 264 between HMEs and NT as opposed to different light conditions.

Co-expression of $c y s-O L E$ and DGAT1 led to the upregulation of a number of genes involved in chloroplastic de novo FA synthesis and in the cases of triacylglycerol lipase sugar-dependent 1 (SDP1), plastidic pyruvate dehydrogenase E1 complex $(P D C)$, and peroxisomal 3-ketoacyl-CoA thiolase 2 (KAT2) there were further significant increases under low light conditions (Figure 4B). In contrast, peroxisomal enoyl-CoA hydratase $1(E C H)$, peroxisomal acetate/butyrate-CoA ligase (AAE7) and phosphatidylcholine:diacylglycerol choline phosphatase (PDCT) were upregulated to approximately the same level in both light conditions whereas the same genes in the NT only matched these levels of expression when the plants were grown under low light conditions (Figure 4B).

Three genes involved in light harvesting genes: chloroplastic chlorophyllase 2 (CLH2), chloroplastic light-regulated protein (LIR); and PSII $10 \mathrm{kDa}$ proteins (PSBR) and three genes involved in regulating water flow: stomatal closure-related actin-binding protein $(S C A B)$; aquaporin tonoplast intrinsic proteins 2-2 \& 4-1 (TIP2-2 \& 4-1) all showed significant genotype $\mathrm{x}$ light treatment interactions (Figure 4C). Where CLH2 expression was significantly reduced in the HMEs under both light regimes and compared to the expression under standard lighting there was a significant reduction in NT under low light. LIR, PSBR, $S C A B$ and TIP2-2 all showed significant increases under low light with the greatest changes occurring in the HMEs, while TIP4-1 was highly expressed in both HMEs under both light conditions in comparison to NT. Rubisco activase $(R C A)$ expression on the other hand was significantly reduced only in the NT under standard lighting (Figure 4C).

The expression of three genes involved in sugar metabolism sucrose-sucrose 1fructosyltransferase (1-SST); phosphoenolpyruvate carboxylate kinase 2 (PEPCK2); and hexokinase 7 (HK7) showed significant genotype x environmental interactions (Fig 4D). Whereas four sugar metabolism related genes showed a significant difference between genotypes only in full light conditions: glyceraldehyde 3-phosphate dehydrogenase $(G 3 P D H)$; sucrose transport protein 2 (SUT2); $\beta$-fructofuranosidase (insoluble invertase) 6 (IVR6); and mitochondrial malate dehydrogenase $(M D H)$. Three genes related to sugar

292 homeostasis and SnRK1/T6P signalling had significant interactions between the genotype 293 and light regime: HK7; trehalose 6-phosphate synthase 1 (TPS1); and SnRK1 (Figure 4E). A 
294 similar response was observed for calcineurin B-like $(C B L)$, a gene involved in $\mathrm{Ca}^{2+}$ 295 signalling related to oxidative stress (Figure 4E). Metacaspase (MCA1) showed a significant 296 genotype difference where the expression level was higher in both HMEs. It should be noted 297 however, that although not significant, the expression level was highest in the HMEs in 298 standard light conditions whereas in NT the opposite was true (Figure 4E).

299 In addition, the expression of two genes involved in nitrogen assimilation: glutamine 300 synthetase $1(G S 1)$ and asparagine synthetase (AS2) and three genes involved in regulating 301 plant growth and development: GA-20 oxidase 2 (GA-20ox2), brassinosteroid LRR receptor 302 kinase (BRI1), and GATA transcription factor 2 all showed significant genotype x light 303 treatment interactions (Figures $4 \mathrm{~F}$ and $4 \mathrm{G}$ ). The expression of $A S 2, G A-200 x 2$, and BRI1 304 were all upregulated in both HMEs under standard lighting and there was a further significant 305 increase under low light conditions whereas the opposite was true for GS1. 


\section{DISCUSSION}

In this study, the performance of HME ryegrass grown under different irradiance levels was investigated. FA, sugars, growth, photosynthesis parameters and transcriptomes were analysed. Overall results suggested molecular mechanisms involve carbon partitioning between TAG accumulation and sugar signalling, and redox potential were differentially regulated in the HME plants compared to the NT. Further discussions related to these altered mechanisms are as follows.

\section{Lipid Metabolism and the Effect of Low Light}

Overexpression of DGAT and cys-OLE promoted carbon flux to FA and TAG synthesis and resulted in changes to the expression pattern of several gene transcripts involving FA elongation, FA desaturation and TAG formation. Increased transcript of a plastidic $P D C$ in the HMEs suggests the plants favoured de novo FA synthesis in the chloroplasts by contributing to acetyl-CoA and NADH production from pyruvate (Ke et al., 2000). PDC transcripts of NT and HMEs were increased in response to low irradiance and was concomitant with a higher FA content of both genotypes. Upregulation of the chloroplastic stearoyl-ACP $\triangle 9$-desaturase transcript in the HMEs correlates with the higher proportion of 18:1 detected in the HME plants (Winichayakul et al., 2020).

Leaf FA composition varies with environmental factors, such as temperature and light and under low irradiance, the light harvesting capacity is usually increased by enhancing the chlorophyll concentration and membrane lipid content of thylakoid per granum (Lichtenthaler et al., 1981; Fuhrmann et al., 2009). Plastid lipid biosynthesis and the degree of thylakoid stacking were significant higher in Arabidopsis grown under low light than the plants grown under high light (Yu et al., 2021). Increased leaf FA and change in FA profiles of NT and HMEs grown under low light likely reflect the altered chloroplast ultrastructure of plants that had adapted to this irradiance (Melis, 1984). It has to be noted that some of the change in leaf FA composition and cys-OLE protein of HMEs under low light may also be influenced by the Rubisco small subunit and $C A B$ promoters used to control the expression of DGAT1 and cys-OLE, respectively. Several studies in both monocot and dicot species have shown that the Rubisco small subunit and $C A B$ promoter activities are positively regulated by light with specifically expressing in chloroplast-containing cells at their highest levels during early leaf development (reviewed in Chory and Susek, 1994; Feng et al., 2014; Mukherjee et al., 2015 and references therein). Under low light, although activity of the $C A B$ promoter used to 
drive the expression of cys-OLE was expected to be repressed, low light HME leaves contained higher cys-OLE than high light leaves. It is remarkable how plants fine-tune FA and glycerolipid biosynthesis to their cellular metabolic need in response to long-term changes in light conditions.

\section{Sequestering of Carbon Forms under Different Irradiances}

Plants fix inorganic $\mathrm{CO}_{2}$ by carboxylating ribulose-bisphosphate, producing a phosphorylated intermediate which is subsequently reduced to triose phosphates (TP) for translocation to the cytosol primarily, but not exclusively, for starch and sucrose synthesis (McClain and Sharkey, 2019). Upregulation of cytosolic triosephosphate isomerase, phosphoglycerate mutase, and pyruvate kinase gene transcripts in HMEs suggests there have been an increase of carbon flow from phosphorylated intermediates into pyruvate. It has been shown that increased lipid biosynthesis in vegetative tissues can lead to a higher capacity of TP utilization; although synthesis of lipid from pyruvate accounts for only 1-3\% of fixed carbon (Bao et al., 2000; Sanjaya et al, 2011). Higher TP utilization can also result in inhibition of starch and sucrose synthesis (McClain and Sharkey, 2019). In our standard lighting environment, we observed downregulation of the leaf cytosolic sucrose synthase and 1-SST gene transcripts in the HMEs which correlates with the lower levels of leaf LMWsugars and fructans, respectively. L. perenne stores very little starch; most of the photosynthetically fixed carbon is directed into sucrose and fructan synthesis (Pollock \& Cairns 1991; Fischer et al., 1997). It is the fact that low light limits carbon capture of the plants and reduces sugar available for transportation through the plant cells. As such biosynthesis of fructan by 1-SST and storage of high molecular weight carbohydrates, which usually occurs when carbon assimilation exceeds carbon use, is therefore significantly reduced (Pollock \& Cairns 1991).

\section{Regulation of Sugar Signalling in Response to Leaf Lipid Sink}

Sugars play a role in the feedback inhibition of photosynthesis though hexokinase and SnRK1/T6P signalling pathways; the processes which have been well-known as the primary components of sugar homeostasis in plants (Rolland et al., 2002; Li and Sheen 2016). When the HME plants were grown in standard lighting conditions they showed increases in the expression of these three sugar sensing regulators. HK7 is a multifunctional hexokinase, regulating glycolytic flux in the cytosol and acting as a glucose sensor in the nucleus (Kim et al., 2016; Aguilera-Alvarado and Sánchez-Nieto 2017). As such it appears that HK7 activity is elevated in the HMEs to provide more substrate for the oxidative pentose phosphate 
372 pathway and subsequent NADPH production which is required for de novo FA synthesis.

373 SnRK1 is a central regulator in adjusting cellular energy and metabolism during starvation,

374 stress and growth-promoting conditions (Tsai and Gazzarrini 2014; Wurzinger et al., 2018).

375 As such, the upregulation of SnRK1 in the HMEs is unsurprising given we have shifted the

376 level of energy and the form of energy. Expression of genes involved in photosynthesis were

377 shown to be activated by SnRK1 overexpression although there is limited evidence for a

378 direct link of this signalling pathway (Baena-Gonzalez et al., 2007; Cho et al., 2012).

379 Antagonistically to SnRK1 activity, T6P elevation by overexpressing TPS1, an enzyme 380 involved in T6P synthesis, can positively impacted photosynthesis (Pellny et al., 2004).

381 However, rather than have a direct sink effect on photosynthesis, T6P changes the 382 distribution of photoassimilate in phloem cells through SWEET genes, triggering sugar 383 demand within the photosynthesis cells (Oszvald et al., 2018). The altered expression of 384 some SWEET genes and TPS1 in the HMEs suggests a role for T6P in balancing sugar 385 homeostasis between source and sink. It is also likely that the increased growth of HMEs 386 results in a greater demand for sugar in the sink tissue which would also reduce the feedback 387 signals that normally downregulate photosynthesis allowing a greater carbon capture (Paul 388 and Foyer 2001; Paul and Eastmond 2020; Beechey-Gradwell et al., 2020).

\section{Light Harvesting and Photosynthesis of the HME and the Effect of Low Light}

390 Under standard lighting, the HMEs enhance their capacity for light absorption by 391 upregulating light regulating proteins as well as downregulating the chloroplastic CLH2, an 392 enzyme involved in chlorophyll breakdown. Upregulation of PSI-related, PSII-related and $393 R C A$ transcripts, including two key photosynthesis regulators; chloroplast ATP synthase and 394 ferredoxin-NADP reductase (FNR), in the HMEs grown under standard light support the 395 greater photosynthetic activity of the plants. Elevated chloroplast ATP synthase and FNR 396 transcripts suggests an increase of both linear and cyclic electron flow around photosystem I. 397 This mechanism is essential for photosynthesis, in particularly the cyclic electron transfer that 398 produces ATP required for driving $\mathrm{CO}_{2}$ fixation (Mulo 2011 and references therein; Bhaduri 399 et. al., 2020). In addition, an increased RCA transcript in the HMEs associated with the 400 plants' greater electron transport suggests modulation of the Rubisco activity may occur 401 (Perdomo et al., 2017).

402 In low light, both NT and HMEs enhanced their capture of light energy by increasing 403 chlorophyll and SLA; although this led to a lower Chlarea it improves light transmission 404 allowing higher $\phi \mathrm{PS} 2$ and potentially increased photosynthesis by the lower leaves (Praba et 
405

406

407

408

409

410

411

412

413

414

415

416

417

418

al., 2011; Hamblin et al., 2014). Low light negatively affects $J$, E and particularly $g_{\mathrm{s}}$ resulting in higher intercellular $\mathrm{CO}_{2}$ and increased leaf $\mathrm{H}_{2} \mathrm{O}$ which limits diffusion capacity and therefore constrains $\mathrm{CO}_{2}$ assimilation (Liu et al., 2014; Zhu et al., 2017). Various genes related to gas, water and solute transport such as SCAB and TIP2-2, TIP4-1 were upregulated in the HMEs, indicating change associated with stomatal conductance and vascular functions, respectively. These three gene transcripts were also increased in NT and HMEs in response to low light. SCAB controls guard cell movement and its inhibition interrupts stomal closure and opening (Zhao et al., 2011). Moreover, it has been suggested that SCAB plays an important role in plant growth under changes of light quality by regulating actin filament dynamic (Wang et al., 2015). Given the abundance of TIP aquaporins in the plant tonoplasts and their redundant roles in membrane transport of water and other small molecules, an accurate explanation for the upregulation of TIP2-2 and TIP4-1 transcripts in the HMEs may be confound without further investigation (Maurel et al., 2015).

\section{Changes in Redox Potential in Response to Leaf Lipid Sink}

The HMEs also differentially manipulate both enzymatic and non-enzymatic mechanisms involved in redox homeostasis such as peroxidases, catalase, amine oxidase, and ascorbateglutathione cycle components as well as L-aspartate oxidase. Combined, these function to remove conjugated glutathione, detoxify peroxidised lipids from the cells and transport oxidative molecules between the cells (Foyer and Noctor 2011). Ascorbate oxidase has a prominent role in the redox homeostasis; therefore, it may be necessary for the HMEs to manipulate the level of this enzyme in order to maintain the redox balance. In addition, increased levels of ascorbate may reduce the recycle of ascorbate from oxidised forms (dehydroascorbate and monodehydroascorbate) and in doing so reserve more reduced forms of glutathione and NADPH (Asada, 2006). Further experiments to determine the change in redox potential of the HME plants will be required.

HMEs appear to differentially regulate specific PIP aquaporins. Several researches have explored the role of PIP to facilitate the retrograde signalling of oxidative compounds, particularly $\mathrm{H}_{2} \mathrm{O}_{2}$ (Bienert and Chaumont 2014). A few possible contributors that may lead to the accumulation of $\mathrm{H}_{2} \mathrm{O}_{2}$ and the altered redox regulation in the HMEs are the elevated levels of FA $\beta$-oxidation in the peroxisomes and the greater electron transport and photosynthesis (Niu and Liao, 2016). In this study we found that numerous transcripts (e.g. SDP1 lipase, KAT2) involving TAG catabolism and peroxisomal oxidation of FA are increased in the HMEs; similar findings were reported in high oil tobacco (Vanhercke et al., 
2017). The functions of SDP1 and other TAG lipases are to synergistically direct FA toward $\beta$-oxidation, thereby maintaining membrane lipid homeostasis (Fan et al., 2014). KAT2, an enzyme involved in the final step of $\beta$-oxidation of FA, was shown to regulate the phytohormone ABA signalling partly through modulating reactive oxygen species (ROS) homeostasis in plant cells (Jiang et al., 2011). Both SDP1 and KAT2 were also upregulated in NT and HMEs in response to low light with significant genotype $\mathrm{x}$ light interaction.

ROS such as $\mathrm{H}_{2} \mathrm{O}_{2}$ are not only considered as cell destructive compounds but act as a signalling molecule in various metabolic processes, including $\mathrm{Ca}^{2+}$ signalling and programme cell-death (Steinhorst and Kudla, 2013; Coll et al., 2010; Černý et al., 2018). Both HMEs had upregulated levels of transcripts for CBL, respiratory burst NADPH oxidase, and MCA1. CBL also increased in NT and HMEs in response to low light while MCA1 only increased in HMEs with no significant difference due to light conditionings. A direct interconnection between CBL-mediated $\mathrm{Ca}^{2+}$ and ROS signalling in plants was reported as evidence for a synergistic activation of the NADPH oxidase, the key producer of ROS in plants (Drerup et al., 2013). Plant metacaspases, represent a family of cysteine proteases which are structurally related to metazoan caspases but are different in their substrate specificity as they cleave at the arginine and lysine residues (Vercammen et al., 2004). MCA1, a type I metacaspase, was found to be a positive regulator of oxidative stress and developmentalinduced cell death (Tsiatsiani et al., 2011). Interestingly, proteome analysis has revealed MCA1 is involved in the dissipation of protein aggregates (Lee et al., 2010). HME may have upregulated MCA1 in response to a cluster of cross-linked cys-OLEs at the closed proximity to the ER during lipid encapsulation. We previously demonstrated that cys-OLE appears to be highly resistant to cysteine protease degradation (Winichayakul et al., 2013) and it would be interesting to examine the stability in the presence of MCA1.

\section{Regulation of Nitrogen Assimilation and Plant Growth and Development in HMEs and the Effect of Low Light}

Our analysis has shown that the leaf $\mathrm{N}_{\text {area }}$ was not significantly different between the HMEs and the NT but decreased under low light. The expression level of two important components of the nitrogen assimilation pathway (GS1 and AS2) were strongly influenced by both genotype and environment, where the cytosolic GS1 transcript was repressed in HMEs and further reduced in low light; the opposite was true for $A S 2$. Expression of $A S$ genes are repressed by sugars and light in a number of plant species (Silvente et al., 2008, and references therein). It has been postulated that the evolutionarily conserved cis-regulatory 
471

472

473

474

475

476

477

478

479

480

481

482

483

elements of the $A S$ promoters mediate sucrose-repression and hexokinase may be involved in this regulation (Irving et al.,2001; Winichayakul et al., 2004). We speculate that the upregulation of $A S 2$ transcript in HMEs may be due to the plants lower sugar content. As for the plants grown under low light, the $A S 2$ gene expression in NT and HMEs may be upregulated directly by physical light signalling and/or indirectly by light levels influencing the sugar content of the plant cells. Three distinct cytosolic GS isoforms from Poaceae family have been reported; these isoenzymes are essential for nitrogen remobilization from senescing leaves to fill grain in annual species (Hirel et al., 2001; Obara et al., 2004; Bernard et al., 2008). Regulation of cytosolic GS1 in ryegrass may be different as the plant is a perennial and the plant materials are vegetative tissues. In addition, the upregulation of $A S 2$ or low sugar may be a feedback signal to reduce cytosolic GS1.

Three genes involved in regulating plant growth and development: GA-20ox2, BRI1 and GATA2 are upregulated in HMEs and in low light. Reducing light intensity was shown to result in an inversely proportional increase in gibberellin content which positively correlated with stem elongation (García-Martinez and Gil, 2002). BRI1 is involved in brassinosteroid signalling cascades during plant development, promotion of cell division and elongation. It has been shown that light and brassinosteroid signalling antagonistically regulate the plant developmental switch from skotomorphogenesis to photomorphogenesis through a key light responsive element G-type GATA2 transcription factor (Luo et al., 2010).

\section{CONCLUSION}

In our previous study we reported that creating stable micro-sinks (lipid droplets) within the photosynthetic cell of the HME plants reduces the availability of primary photosynthate (sugars). In turn this reduces the diurnal build-up of carbohydrates and as such prevents the feedback inhibition on photosynthesis. This is the first study to report on transcript expression in these plants. Many of the upregulated transcripts were from genes involved in lipid metabolism, light capturing, and photosynthesis. These were also shown to be modulated by the low intensity of the photosynthetic light. The results from this study suggest that our development of HME ryegrass should provide a promising towards delivering pasture sward (low light field canopy) with higher lipid. However, the secondary effect of HME expression that increases photosynthesis and growth yield of the plants may be not efficiently translated from the laboratory spaced pots to sward canopy, due to shading conditions. 
In addition, we also reported that expression of genes involved in sugar signalling and redox homoeostasis was influenced by the accumulation of lipid droplets in the leaf. Further studies on the regulatory network such as nitrogen metabolism, phytohormone signalling, sugar regulation and redox homeostasis are needed to provide an insight into underlying mechanisms which have been altered in response to storing carbon as leaf lipid sink.

\section{MATERIALS AND METHODS}

\section{Plant Material and Experiment Design}

Three independent $\mathrm{T}_{0}$ HME transgenic ryegrass lines (HME30, HME34, and HME42) and a respective NT control (Impact cultivar clone 93) were propagated into $1.3 \mathrm{~L}$ potting mix soil to generate multiple isogenic clones of each. These transgenic lines were selected due to their range of leaf FA content. Thirty plantlets of 5-tiller each genotype were transplanted into $1.3 \mathrm{~L}$ washed coarse sand (Daltons, NZ) flushed with $2 \mathrm{mM} \mathrm{KNO}_{3}$ containing nutrient solution (Andrews et al., 1992). Plants were grown in a controlled environment room (22/15 ${ }^{\circ} \mathrm{C}$ day/night temperature, $65-70 \%$ humidity, $10 \mathrm{~h}$ day-light intensity of $300-400 \mu \mathrm{mol} \mathrm{m}^{-2} \mathrm{~s}^{-1}$ ) and fed with $50 \mathrm{~mL}$ of $2 \mathrm{mM} \mathrm{KNO}_{3}$ containing nutrient solution, 3 times a week. Pots were rotated along the bench every 2-3 d to provide uniform exposure to the growth conditions.

Three weeks after establishment, randomly selected 10 plants from each genotype were harvested. The remaining 20 plants of each genotype were divided into 2 groups for a comparison between standard (600-1000 $\left.\mu \mathrm{mol} \mathrm{m}^{-2} \mathrm{~s}^{-1}\right)$ and low $\left(150-250 \mu \mathrm{mol} \mathrm{m}^{-2} \mathrm{~s}^{-1}\right)$ light densities. Plants were grown for another 3 weeks and fed with $50 \mathrm{~mL}$ of $4 \mathrm{mM} \mathrm{NH} 4 \mathrm{NO}_{3}$ containing nutrient solution, 3 times a week and every day during the last week. One week prior to the final harvest, plants were measured for photosynthetic parameters.

\section{Harvest, Leaf Water Content and Relative Growth Rate}

Plants were harvested after 3-week establishment and divided into 'leaf' (leaf blade and leaf sheath from $6 \mathrm{~cm}$ above the sand surface), 'sheath' (leaf sheaths on a tiller or pseudostem, $6 \mathrm{~cm}$ from the sand surface), and roots (cleaned). These plant materials were oven dried at $65{ }^{\circ} \mathrm{C}$ for approximately $3-4 \mathrm{~d}$ and weighted for the $\mathrm{DW}$ establish. At final harvest, plant materials were sampled as above. Small aliquots of leaf were subsampled, weighted for fresh weight $\left(\mathrm{FW}^{1}\right)$, and oven dried for dry weight $\left(\mathrm{DW}^{1}\right)$. The remaining leaf material, sheath and roots were freeze-dried for 3-4 d for DW final. Leaf water content was calculated using a classical assessment based on the weight change between fresh and dried leaves as the following:

$$
\text { Leaf water }(\%)=\left(\mathrm{FW}^{1}-\mathrm{DW}^{1}\right) / \mathrm{FW}^{1 *} 100
$$


In this study, RGR is preferred than DW in order to eliminate ambiguous differences of DW data resulted from propagation. RGR was calculated from the average of $\mathrm{DW}_{\text {establish }}$ and individual $\mathrm{DW}_{\text {final }}$ as the following:

$$
\text { Leaf } \mathrm{RGR}=\left(\ln \left[\mathrm{DW}_{\text {final }}+\mathrm{DW}^{1}\right]-\ln \left[\mathrm{DW}_{\text {establish }}\right) /\left(\text { t }_{\text {final }}-\mathrm{t}_{\text {establish }}\right)\right.
$$

where $\mathrm{t}$ is time between established and final harvests.

$$
\text { Sheath or root } \mathrm{RGR}=\left(\ln \left[\mathrm{DW}_{\text {final }}\right]-\ln [\mathrm{DW} \text { establish }]\right) /\left(\text { tfinal }_{\text {festablish }}\right)
$$

\section{Lipid and Sugar Analyzes}

The lyophilized ground leaves and sheath were analyzed for FA and sugars. FA were extracted from approximately $10 \mathrm{mg}$ DW and methylated according to Browse et al., (1986). FA were verified and analyzed by gas chromatography-flame ionization detector (Shimadzu QP2010, Zebron ${ }^{\mathrm{TM}}$ ZB-FAME column (7FD-G033-05)) using Supelco® 37 component FAME standard mix (Merck, CRM47885). The internal pentadecyclic acid (15:0, added prior to methylation) and methylated margaric acid (17:0) standards were used for quantification. Total FA concentration presented as percentage of plant dry weight are the sum of palmitic acid (16:0), palmitoleic acid (16:1), stearic acid (18:0), linoleic acid (18:1), linolenic acid (18:3), arachidic acid (20:0), gondoic acid (20:1), behenic acid (22:0), and erucic acid (22:1).

For water-soluble sugars, approximately a $25 \mathrm{mg}$ sample was extracted in $80 \%$ ethanol (v/v) and $\mathrm{H}_{2} \mathrm{O}$ for LMW- and HMW-sugars, respectively (Winichayakul et al., 2020). The colorimetric reaction was developed using anthrone assay as described in Jermyn, (1975) and measured at $620 \mathrm{~nm}$. Sugars were quantified using a dilution series of sucrose and inulin standards.

\section{Leaf Carbon and Nitrogen Content}

The lyophilized ground leaf materials were placed in a drying oven at $30{ }^{\circ} \mathrm{C}$ for $15-20 \mathrm{~min}$ and approximately $100 \mathrm{mg}$ DW were taken. Samples were repeatedly ground through a $1 \mathrm{~mm}$ sieve and analysed for total $\mathrm{N}$ and $\mathrm{C}$ content by thermal conductivity detection using a combustion elemental analyser (vario MAX cube CNS; Elementar Analysensteme GmbH, Langenselbold, Germany).

\section{SDS-PAGE Analysis of cys-OLE}

Protein samples were prepared by vigorously mixing $10 \mathrm{mg}$ of lyophilized ground material with $150 \mu \mathrm{L}$ of sterile $\mathrm{H}_{2} \mathrm{O}, 200 \mu \mathrm{L}$ of $2 \mathrm{X}$ loading buffer (1:2 diluted $4 \mathrm{X}$ lithium dodecyl sulfate sample buffer [Thermo Fisher NP0007], $8 \mathrm{M}$ urea, 4\% [v/v] triton X-100, and $5 \%[\mathrm{v} / \mathrm{v}] \beta$-mercaptoethanol), and $40 \mu \mathrm{L}$ of $10 \mathrm{X}$ reducing agent (Thermo Fisher NP0004). 
Equal volumes of leaf protein were separated by SDS-PAGE (Mini-PROTEAN® TGX stainfree $^{\mathrm{TM}}$ precast gels; Bio-Rad system) and cys-OLE was detected by immunoblotting as described in Winichayakul et al., (2013). Chemiluminescent activity was developed using WesternBright ECL spray (Advansta, CA) and visualized by the Bio-Rad ChemiDoc ${ }^{\mathrm{TM}}$ imaging system. Volume intensity of protein bands was quantified using Image Lab software for PC version 5.2.1 (Bio-Rad).

\section{Chlorophyll Concentration}

Chlorophyll $(C h l)$ was extracted from approximately $15 \mathrm{mg}$ of lyophilized ground leaf materials with $3 \mathrm{~mL}$ of $95 \%$ [v/v] ethanol. Extraction tubes (sealed with Teflon lined screw cap) were kept at room temperature in dark for $4 \mathrm{~h}$ with interval thoroughly mixing. The extracts were $1 / 4$ diluted before colorimetric measurement. Concentration of chlorophyll in extracts was measured spectrophotometrically (VersaMax ${ }^{\mathrm{TM}}$ microplate reader) at the wavelengths of $648 \mathrm{~nm}$ and $664 \mathrm{~nm}$ and calculated for $C h l_{a}$ and $C h l_{b}$ contents as described by Miazek and Ledakowicz (2013). Microplate absorbance from $200 \mu \mathrm{l}$ of an ethanol extract was adjusted to $1-\mathrm{cm}$ pathlength spectrophotometer with modification of 1/0.51 co-factors according to a report by Warren (2008).

\section{Photosynthetic Gas Exchange}

Three tillers were selected per plant, and on the youngest fully expanded leaves, net photosynthesis per unit leaf area, transpiration, stomatal conductance, electron transportation rate and quantum efficiency of PSII was analyzed using a Licor 6800 infrared gas exchange system (Licor Biosciences Ltd., Nebraska, USA). Leaves were acclimated under growing conditions: 200 and $700 \mu \mathrm{mol}$ photons $\mathrm{m}^{-2} \mathrm{~s}^{-1} \mathrm{red} / \mathrm{blue}$ light for low and standard light treatments respectively, $400 \mathrm{ppm} \mathrm{CO}, 70 \%$ relative humidity and $20^{\circ} \mathrm{C}$ for 15 min prior to 595 data-logging. The three leaves were then abscised, photographed, oven dried and weighed. Leaf area was calculated using GIMP 2.8.22 (GNU Image Manipulation Program, http://www.gimp.org) and specific leaf area was calculated as a $\mathrm{m}^{2}$ of leaf area per $\mathrm{kg} \mathrm{DW}$.

\section{RNA Isolation and Sequencing}

Two HMEs (HME34 and HME 42) were tested for transcriptome analysis in this study. 
602 instructions. Total RNA $(2-3 \mu \mathrm{g})$ was dried down and preserved in Sigma-Aldrich

603 RNAstable ${ }^{\circledR}$ before being couriered to BGI Tech Solutions (Hongkong) Co., Ltd. BGI Tech

604 prepared and processed libraries for 20M PE100 reads using their DNBseq platform.

605

606

607

608

\section{Transcriptome Assembly, Expression Analysis and Annotation}

The provided reads were assembled using Trinity v2.7.0 with a minimum contig length of 300 bp. Statistics were derived using BWA and Samtools. Differential expression levels were determined in R using DESeq and Biostrings. Differentially expressed contigs were firstly selected for those with padj $<0.001$, and then those contigs were further refined by selecting for $(\log 2)$-fold change ranged from \pm 1 to \pm 14 . Local BLAST searches of the Oryza sativa IRGSP-1.0 and the Brachypodium distachyon databases provided best-hit identification of the differentially expressed contigs. Metabolic gene classes were taken as assigned by the KEGG database (Kanehisa and Goto, 2000) and UniProt Knowledgebase.

\section{Statistical Analysis}

Experiment data were analysed by one-way or two-way ANOVA using the RStudio version 3.6.0 with a model that included fixed effect of ryegrass genotypes (HMEs and NT) and light densities (standard and low lights). In some cases, a log-transformation was applied to the responses for matching the normality assumption of ANOVA. A multiple comparison of treatments such as Bartlett's test (homogeneity of variances) and Shapiro-Wilk normality test from ANOVA was used to highlight significant among treatment means while $P$ values were adjusted by the $\mathrm{BH}$ method (Benjamini and Hochberg, 1995) to control the false discovering rate. Means and LSD are reported, and fixed effects declared significant at $P<$ 0.05 .

\section{Supplemental Data}

The following supplemental material is available.

Supplemental Figure S1.

\section{ACKNOWLEDGEMENTS}

This manuscript was funded by AgResearch Science Prize 2017 and the New Zealand Ministry of Business, Innovation and Employment through the research programme (C10X1603). 
bioRxiv preprint doi: https://doi.org/10.1101/2021.05.09.443314; this version posted May 10, 2021. The copyright holder for this preprint (which was not certified by peer review) is the author/funder, who has granted bioRxiv a license to display the preprint in perpetuity. It is made available under aCC-BY-NC-ND 4.0 International license.

633

634

635

636 
Table 1. Effect of low light on total fatty acid and sugars in high lipid ryegrass and control.

\begin{tabular}{|c|c|c|c|c|c|c|c|c|}
\hline \multirow{2}{*}{ Genotype } & \multirow[b]{2}{*}{ Light } & \multicolumn{4}{|c|}{ Leaves } & \multicolumn{3}{|c|}{ Sheath } \\
\hline & & $\begin{array}{c}\text { FA } \\
(\% \text { DW })\end{array}$ & $\begin{array}{l}\text { cys-OLE* } \\
\left(\mathrm{x} 10^{6}\right)\end{array}$ & $\begin{array}{c}\text { HMW } \\
\left(\mathrm{g} \mathrm{kg}^{-1} \mathrm{DW}\right)\end{array}$ & $\begin{array}{c}\mathrm{LMW} \\
\left(\mathrm{g} \mathrm{kg}^{-1} \mathrm{DW}\right)\end{array}$ & $\begin{array}{c}\text { FA } \\
(\% \text { DW })\end{array}$ & $\begin{array}{c}\text { HMW } \\
\left(\mathrm{g} \mathrm{kg}^{-1} \mathrm{DW}\right)\end{array}$ & $\begin{array}{c}{ }^{1} \mathrm{LMW} \\
\left(\mathrm{g} \mathrm{kg}^{-1} \mathrm{DW}\right)\end{array}$ \\
\hline NT & Standard & $3.69 \mathrm{~F}$ & nd & $63.51 \mathrm{~A}$ & $106.31 \mathrm{~A}$ & $2.17 \mathrm{~F}$ & $99.83 \mathrm{~A}$ & $69.18 \mathrm{~A}$ \\
\hline HME30 & Standard & $5.74 \mathrm{D}$ & $14.33 \mathrm{D}$ & $62.38 \mathrm{~A}$ & $85.91 \mathrm{~B}$ & $2.80 \mathrm{E}$ & $102.01 \mathrm{~A}$ & $59.69 \mathrm{BC}$ \\
\hline HME34 & Standard & $6.40 \mathrm{C}$ & $30.37 \mathrm{BC}$ & $54.77 \mathrm{~B}$ & 86.48 B & $3.53 \mathrm{BC}$ & $96.98 \mathrm{~A}$ & $60.33 \mathrm{~B}$ \\
\hline HME42 & Standard & $5.93 \mathrm{D}$ & $24.53 \mathrm{C}$ & $54.40 \mathrm{~B}$ & $83.67 \mathrm{~B}$ & $3.05 \mathrm{D}$ & $105.65 \mathrm{~A}$ & $55.94 \mathrm{C}$ \\
\hline NT & Low & $4.22 \mathrm{E}$ & nd & $1.09 \mathrm{C}$ & $42.78 \mathrm{C}$ & $2.25 \mathrm{~F}$ & $6.75 \mathrm{~B}$ & $32.02 \mathrm{D}$ \\
\hline HME30 & Low & $6.91 \mathrm{~B}$ & $39.03 \mathrm{~B}$ & $0.78 \mathrm{C}$ & $34.51 \mathrm{CD}$ & $3.15 \mathrm{D}$ & $6.18 \mathrm{~B}$ & $30.00 \mathrm{DE}$ \\
\hline HME34 & Low & $7.38 \mathrm{~A}$ & $48.54 \mathrm{~A}$ & $0.72 \mathrm{C}$ & $37.22 \mathrm{CD}$ & $3.86 \mathrm{~A}$ & $5.84 \mathrm{~B}$ & $28.93 \mathrm{DE}$ \\
\hline HME42 & Low & $6.95 \mathrm{~B}$ & $36.84 \mathrm{~B}$ & $0.60 \mathrm{C}$ & $33.52 \mathrm{D}$ & $3.40 \mathrm{C}$ & $7.39 \mathrm{~B}$ & $27.57 \mathrm{E}$ \\
\hline $\operatorname{LSD}\left(95^{\circ}\right.$ & Confidence) & 0.29 & 8.43 & 7.71 & 8.46 & 0.19 & 11.78 & 4.09 \\
\hline
\end{tabular}

A-F Means within a column with different alphabets differ $(P<0.05)$. $\mathrm{df}=71(n=9$ or 10$)$.

$639 \mathrm{NT}=$ non-transformed plants; $\mathrm{HME}=$ high metabolizable energy ryegrass; FA = fatty acids; DW = dry weight;

640 cys-OLE = cysteine-oleosin signal intensity detected from immunoblotting (

HMW = high molecular weight sugars; LMW = low molecular weight sugars; nd = not detectable. 
Table 2. Effect of low light on specific leaf area, leaf-to-root ratio, nitrogen content per leaf area, carbon content per dry mass, leaf water, and chlorophyll in high lipid ryegrass and control.

\begin{tabular}{|c|c|c|c|c|c|c|c|c|}
\hline Genotype & Light & $\begin{array}{c}\mathrm{SLA}^{1} \\
\mathrm{~m}^{2} \mathrm{~kg}^{-1} \mathrm{DW}\end{array}$ & $\begin{array}{c}{ }^{1} \mathrm{~L} / \mathrm{R} \\
\mathrm{g} \mathrm{g}^{-1} \mathrm{DW}\end{array}$ & $\begin{array}{l}\mathrm{N}_{\text {area }} * \\
\mathrm{~g} \mathrm{~m}^{-2}\end{array}$ & $\% \mathrm{C}^{*}$ & $\begin{array}{c}\text { Leaf water } \\
\%\end{array}$ & $\begin{array}{c}\mathrm{Chl} \\
\mathrm{mmol} \mathrm{kg}^{-1} \mathrm{DW}\end{array}$ & $\begin{array}{l}\mathrm{Chl}_{\text {area }} \\
\mathrm{mmol} \mathrm{m}^{-2}\end{array}$ \\
\hline NT & Standard & $18.79 \mathrm{~B}$ & $0.81 \mathrm{~B}$ & $2.32 \mathrm{~A}$ & $42.87 \mathrm{~B}$ & $71.77 \mathrm{D}$ & $9.59 \mathrm{D}$ & $0.51 \mathrm{BC}$ \\
\hline HME30 & Standard & $19.12 \mathrm{~B}$ & $0.59 \mathrm{C}$ & $2.25 \mathrm{~A}$ & $44.10 \mathrm{~A}$ & $75.47 \mathrm{C}$ & $10.45 \mathrm{C}$ & $0.55 \mathrm{AB}$ \\
\hline HME34 & Standard & $19.83 \mathrm{~B}$ & $0.53 \mathrm{C}$ & $2.22 \mathrm{~A}$ & $44.36 \mathrm{~A}$ & $75.75 \mathrm{C}$ & $10.73 \mathrm{BC}$ & $0.55 \mathrm{AB}$ \\
\hline HME42 & Standard & $19.68 \mathrm{~B}$ & $0.59 \mathrm{C}$ & $2.20 \mathrm{~A}$ & $44.37 \mathrm{~A}$ & $77.15 \mathrm{~B}$ & $11.45 \mathrm{~B}$ & $0.59 \mathrm{~A}$ \\
\hline NT & Low & $32.35 \mathrm{~A}$ & $1.85 \mathrm{~A}$ & $1.66 \mathrm{~B}$ & $41.14 \mathrm{E}$ & $83.90 \mathrm{~A}$ & $15.16 \mathrm{~A}$ & $0.47 \mathrm{CD}$ \\
\hline HME30 & Low & $34.24 \mathrm{~A}$ & $1.73 \mathrm{~A}$ & $1.61 \mathrm{~B}$ & $42.12 \mathrm{D}$ & $83.92 \mathrm{~A}$ & $14.59 \mathrm{~A}$ & $0.43 \mathrm{D}$ \\
\hline HME34 & Low & $34.59 \mathrm{~A}$ & $1.80 \mathrm{~A}$ & $1.60 \mathrm{~B}$ & $42.51 \mathrm{C}$ & $83.87 \mathrm{~A}$ & $15.14 \mathrm{~A}$ & $0.45 \mathrm{D}$ \\
\hline HME42 & Low & $32.20 \mathrm{~A}$ & $1.75 \mathrm{~A}$ & $1.71 \mathrm{~B}$ & $42.32 \mathrm{CD}$ & $83.84 \mathrm{~A}$ & $14.76 \mathrm{~A}$ & $0.45 \mathrm{CD}$ \\
\hline \multicolumn{2}{|c|}{ LSD (95\% Confidence) } & 0.19 & 0.21 & 2.78 & 0.28 & 1.12 & 0.75 & 0.05 \\
\hline
\end{tabular}

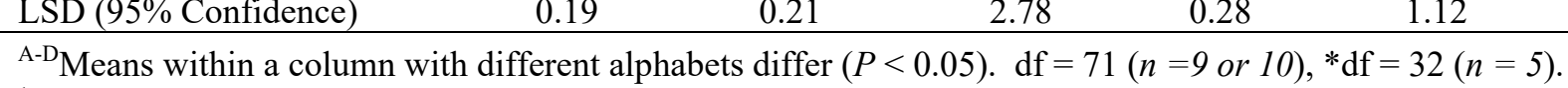

$653 \quad{ }^{\text {A-D }}$ Means within a column with different alpha

$655 \mathrm{NT}=$ non-transformed plants; HME = high metabolizable energy ryegrass; SLA = specific leaf area (projected leaf area per unit

656 leaf dry mass) $\mathrm{L} / \mathrm{R}=$ leaf-to-root ratios; $\mathrm{N}_{\text {area }}=$ total leaf nitrogen per unit of leaf area; \% $\mathrm{C}=$ carbon content per dry mass;

$657 \mathrm{Chl}=$ chlorophyll; $\mathrm{Chl}_{\text {area }}=$ leaf chlorophyll per unit of leaf area. 
668 Table 3. Effect of low light on photosynthesis parameters of high lipid ryegrass and control.

\begin{tabular}{|c|c|c|c|c|c|c|}
\hline Genotype & Light & 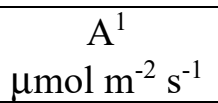 & 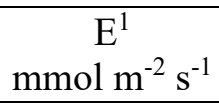 & $\begin{array}{c}g_{\mathrm{s}}{ }^{1} \\
\mathrm{mmol} \mathrm{m}^{-2} \mathrm{~s}^{-1}\end{array}$ & $\begin{array}{c}J \\
\mu \mathrm{mol} \mathrm{m} \mathrm{m}^{-2} \mathrm{~s}^{-1}\end{array}$ & $\phi$ PS2 \\
\hline NT & Standard & $17.97 \mathrm{C}$ & $1.70 \mathrm{BC}$ & $224.51 \mathrm{~B}$ & $148.12 \mathrm{~B}$ & $0.50 \mathrm{C}$ \\
\hline HME30 & Standard & $20.87 \mathrm{AB}$ & $1.96 \mathrm{AB}$ & $263.98 \mathrm{AB}$ & $156.92 \mathrm{~A}$ & $0.53 \mathrm{~B}$ \\
\hline HME34 & Standard & $19.00 \mathrm{BC}$ & $1.79 \mathrm{C}$ & $240.11 \mathrm{~B}$ & $153.32 \mathrm{AB}$ & $0.52 \mathrm{BC}$ \\
\hline HME42 & Standard & $22.46 \mathrm{~A}$ & $2.21 \mathrm{~A}$ & $300.20 \mathrm{~A}$ & $158.22 \mathrm{~A}$ & $0.54 \mathrm{~B}$ \\
\hline NT & Low & $8.00 \mathrm{D}$ & $0.87 \mathrm{D}$ & $119.21 \mathrm{C}$ & $56.30 \mathrm{C}$ & $0.67 \mathrm{~A}$ \\
\hline HME30 & Low & $8.52 \mathrm{D}$ & $0.96 \mathrm{D}$ & $133.29 \mathrm{C}$ & $55.60 \mathrm{C}$ & $0.66 \mathrm{~A}$ \\
\hline HME34 & Low & $8.73 \mathrm{D}$ & $0.92 \mathrm{D}$ & $125.89 \mathrm{C}$ & $56.98 \mathrm{C}$ & $0.68 \mathrm{~A}$ \\
\hline HME42 & Low & $8.54 \mathrm{D}$ & $0.94 \mathrm{D}$ & $128.95 \mathrm{C}$ & $57.35 \mathrm{C}$ & $0.68 \mathrm{~A}$ \\
\hline LSD $(95 \%$ & onfidence) & 2.09 & 0.28 & 39.40 & 5.65 & 0.02 \\
\hline
\end{tabular}

Confidence

39.40

5.65

${ }^{A-D}$ Means within a column with different superscripts differ $(P<0.05)$. df $=72(n=10)$.

$670 \quad{ }^{1}$ Data were analyzed using log-transformation.

$671 \mathrm{NT}=$ non-transformed plants; HME = high metabolizable energy ryegrass; $\mathrm{A}=$ the rate of photosynthesis per unit leaf area;

$672 \mathrm{E}=$ transpiration rate; $g_{\mathrm{s}}=$ stomatal conductance; $J=$ electron transportation rate per unit leaf area;

$673 \phi_{\mathrm{PS} 2}=$ quantum efficiency of PSII. 

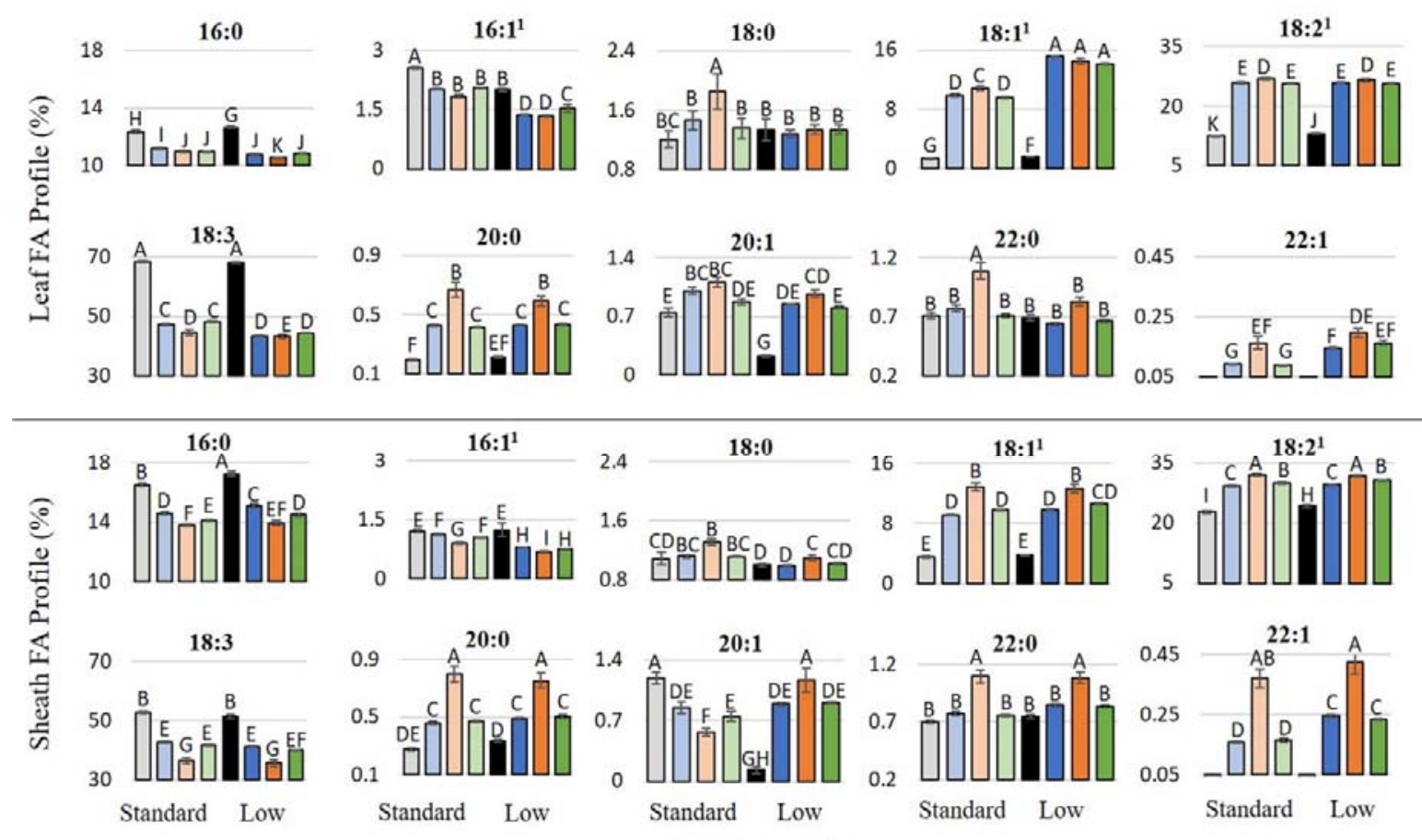

Growth Irradiance from material of high lipid ryegrass and control harvested after 21 days regrowth.

Data presented as mean percentages of total fatty acids \pm SE from separate analysis ( $\mathrm{df}=143, n=9$ or 10$)$.

${ }^{\mathrm{A}-\mathrm{K}}$ Alphabets indicated significant differences $(P<0.05)$. ${ }^{1}$ Data were analyzed using log-transformation. 

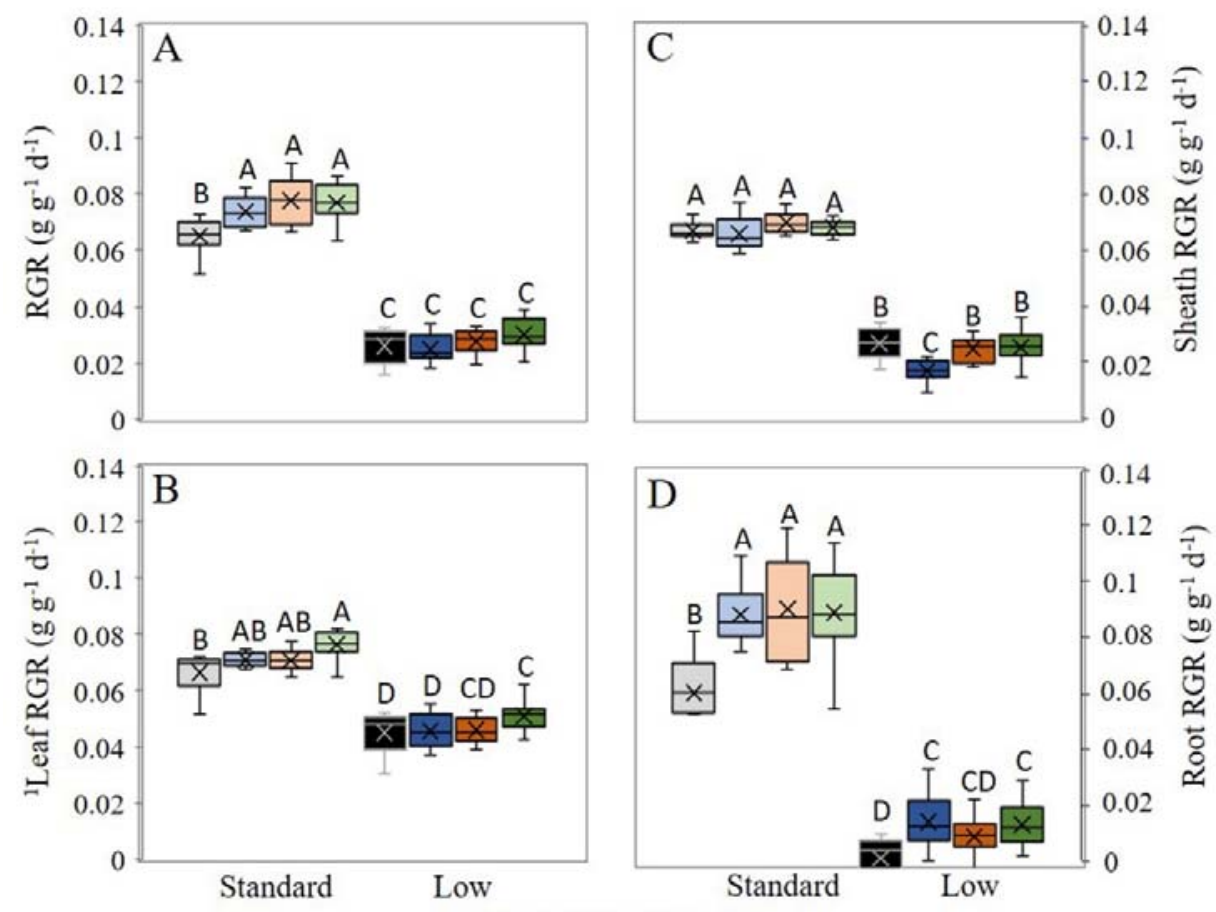

Growth Irradiance

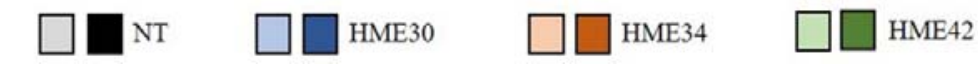

696 Figure 2. Box and whisker plots of relative growth rate (RGR, $\left.\mathrm{g} \mathrm{g}^{-1} \mathrm{~d}^{-1}\right)$ of high lipid ryegrass and control grown under standard and low lights. (A) RGR of total mass (B) leaf RGR (C) sheath RGR and (D) root RGR.

A-D Alphabets indicated significant differences $(P<0.05) . \mathrm{df}=71(n=9$ or 10$)$.

${ }^{1}$ Data were analyzed using log-transformation.

$\mathrm{WT}=$ non-transformed plants; HME $=$ high metabolizable energy ryegrass;

703

RGR calculated as $\left(\ln \mathrm{W}_{2}-\ln \mathrm{W}_{1}\right) /\left(\mathrm{t}_{2}-\mathrm{t}_{1}\right)$, where $\mathrm{W}_{1}$ and $\mathrm{W}_{2}$ were plant dry weights at times $\mathrm{t}_{1}$ and $\mathrm{t}_{2}$. 
bioRxiv preprint doi: https://doi.org/10.1101/2021.05.09.443314; this version posted May 10, 2021. The copyright holder for this preprint (which was not certified by peer review) is the author/funder, who has granted bioRxiv a license to display the preprint in perpetuity. It is made available under aCC-BY-NC-ND 4.0 International license.
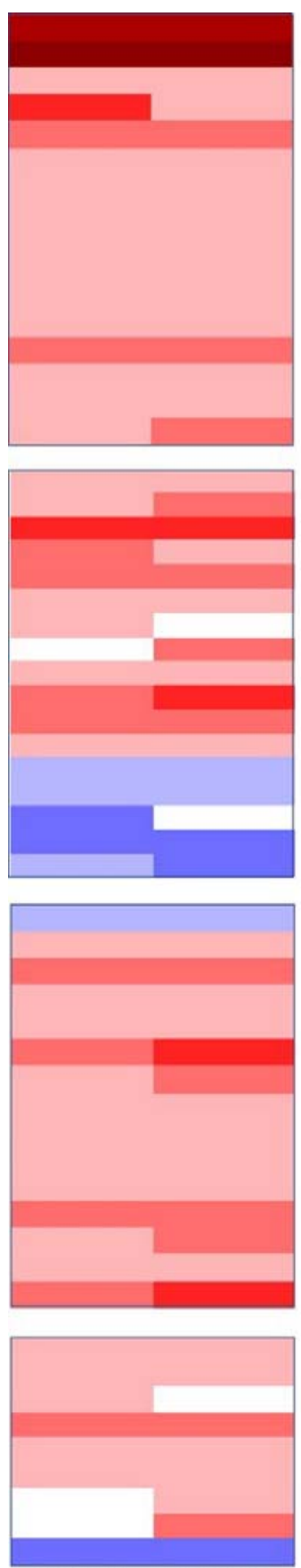

706

HME34 HME42
XP_015634024.1 oleosin 16 kDa-like

XP_015641041.1 diacylglycerol O-acyltransferase 1-2

XP_015636508.1 pyruvate dehydrogenase E1 component subunit alpha

XP_015630103.1 stearoyl-[acyl-carrier-protein] 9-desaturase 1, chloroplastic

XP_025877699.1 enoyl-[acyl-carrier-protein] reductase

XP_015649041.1 phospholipase A1-lbeta2, chloroplastic

XP_015628879.1 phospholipase D alpha 1

XP_015636240.1 glycerol kinase

XP_015614524.2 glycerol-3-phosphate 2-0-acyltransferase 6

XP_015627625.1 probable glycerol-3-phosphate acyitransferase 3

XP_015644243.1 phosphatidylcholine:diacylglycerol cholinephosphatase

XP_015621385.1 triacylglycerol lipase SDP1

XP_015625435.13-ketoacyl-CoA thiolase 2, peroxisomal

XP_015632322.1 probable enoyl-COA hydratase 1 , peroxisomal

XP_015631446.1 acetate/butyrate--COA ligase AAE7, peroxisomal

XP_015632927.1 acetate/butyrate-COA ligase AAE7, peroxisomal

XP_015621507.1 triosephosphate isomerase, cytosolic

XP_015636363.1 phosphoglycerate mutase-like protein 1 isoform X1

XP_015619741.1 pyruvate kinase, cytosolic

$X P_{-}$-015623120.1 phosphoenolpyruvate carboxylase kinase 2

XP_015624648.1 phosphoenolpyruvate carboxylase 1

XP_003569476.1 isocitrate dehydrogenase [NADP], cytosolic

XP_015625273.1 beta-fructofuranosidase 1

XP_015629643.1 beta-fructofuranosidase 3

XP_ 015634384.1 beta-fructofuranosidase 6

XP 015612113.1 alpha-amylase 3B

XP_015650046.1 alpha-amylase 3D

XP_015614561.1 soluble starch synthase 2-1, chloroplastic/amyloplastic

XP_015650130.1 glyceraldehyde-3-phosphate dehydrogenase 1, cytosolic

XP_015635626.1 glyceraldehyde-3-phosphate dehydrogenase 2, cytosolic

XP_025882333.1 sucrose synthase 2

$X P_{-} 015634274.1$ sucrose synthase 7

XP-015625788.1 sucrose:sucrose 1-fructosyitransferase

XP_015613138.1 chlorophyllase-2, chloroplastic

XP_014754487.1 light-regulated protein, chloroplastic

XP_015617278.1 light-regulated protein, chloroplastic

NP_039383.1 photosystem I P700 chlorophyll a apoprotein A1

XP_015650464.1 photosynthetic NDH subunit of subcomplex B 1, chloroplastic

XP_003557641.1 photosystem II $10 \mathrm{KDa}$ polypeptide

YP_002000472.1 photosystem II protein I

XP_015635865.1 psbP domain-containing protein 2, chloroplastic

XP_015640980.1 ferredoxin-NADP reductase, leaf isozyme 1, chloroplastic

NP_039390.1 ATP synthase CF1 beta subunit (plastid)

XP_015616897.1 ribulose bisphosphate carboxylase/oxygenase activase

XP_015628507.2 stomatal closure-related actin-binding protein 1

XP_015628509.1 stomatal closure-related actin-binding protein 1

XP_015643913.1 probable aquaporin TIP2-2

XP_015640527.1 probable aquaporin TIP4-1

XP_015637554.1 hexokinase 7

XP_015611910.1 alpha,alpha-trehalose-phosphate synthase 1

XP_015640390.1 alpha,alpha-trehalose-phosphate synthase

XP_015616061.1 SNF1-related protein kinase regulatory subunit gamma

XP_015635849.1 SNF1-related protein kinase regulatory subunit gamma

XP_025878169.1 bidirectional sugar transporter SWEET1a

XP_015610839.1 bidirectional sugar transporter SWEET1a

XP_015626955.1 bidirectional sugar transporter SWEET4

XP_015619426.1 bidirectional sugar transporter SWEET2b 
bioRxiv preprint doi: https://doi.org/10.1101/2021.05.09.443314; this version posted May 10, 2021. The copyright holder for this preprint (which was not certified by peer review) is the author/funder, who has granted bioRxiv a license to display the preprint in perpetuity. It is made available under aCC-BY-NC-ND 4.0 International license.
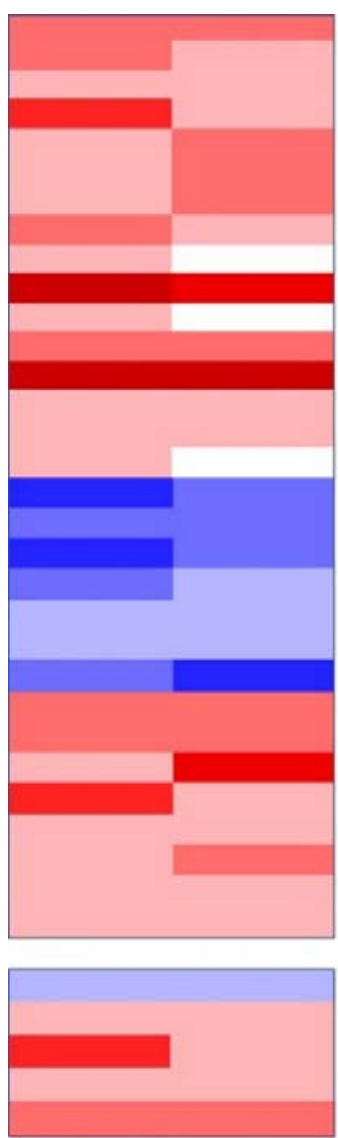

HME34 HME42
XP 015645086.1 peroxidase 1-like

XP_014756014.1 peroxidase 5

XP_015622358.1 peroxidase 24

XP 015625546.1 peroxidase 70

XP_003573241.1 catalase 2

XP_015646033.1 primary amine oxidase 2

XP_015649937.1 monodehydroascorbate reductase 4, cytosolic-like

XP_003567688.1 glutaredoxin-C1

XP_025882347.1 putative glutaredoxin-C2

XP_003565017.1 glutathione S-transferase 3

XP_015645399.1 glutathione S-transferase 4

XP_015643663.1 probable glutathione S-transferase GSTF1

XP_015614527.1 probable glutathione S-transferase GSTU6

XP_015623154.1 quinone oxidoreductase PIG3

XP_003564899.1 thioredoxin F, chloroplastic

XP_015623260.1 thioredoxin-like 3-1, chloroplastic

XP_015643242.1 L-ascorbate oxidase X2

XP $015611052.1 \mathrm{~L}$-ascorbate oxidase

XP_015641225.1 L-ascorbate oxidase

XP_015612667.1 L-ascorbate oxidase 150

XP_015625393.1 aquaporin PIP1-1

XP_015625572.1 aquaporin PIP 1-3

XP_015644586.1 aquaporin PIP2-4

XP 003503177.1 probable

$X P$-003580150.1 aquaporin PIP2-5

XP_015622592.1 calcineurin subunit $B$

XP_015632155.1 calcineurin B-like protein 3

XP_015637956.1 calcineurin B-llike protein 4-X2

XP_015639820.1 respiratory burst oxidase homolog protein A

XP_015650217.1 respiratory burst oxidase homolog protein $E$

XP_015628328.1 metacaspase-1

XP_015626102.1 glutamine synthetase cytosolic isozyme 1

XP_015643183.1 asparagine synthetase 2 [glutamine-hydrolyzing]

XP_015627721.1 gibberellin 20 oxidase 2

XP_ 015621030.1 brassinosteroid LRR receptor kinase BRI1

XP_015613303.1 GATA transcription factor 2

×ั

¿ृँ

709

710 Figure 3. Differential gene expression in high metabolizable energy (HME) ryegrass to non711 transformed plants (NT). Colour of the boxes present (Log2)-fold change values relative to 712 NT at significant $P<0.001(n=3)$.

713

714

715

716

717

718

719 


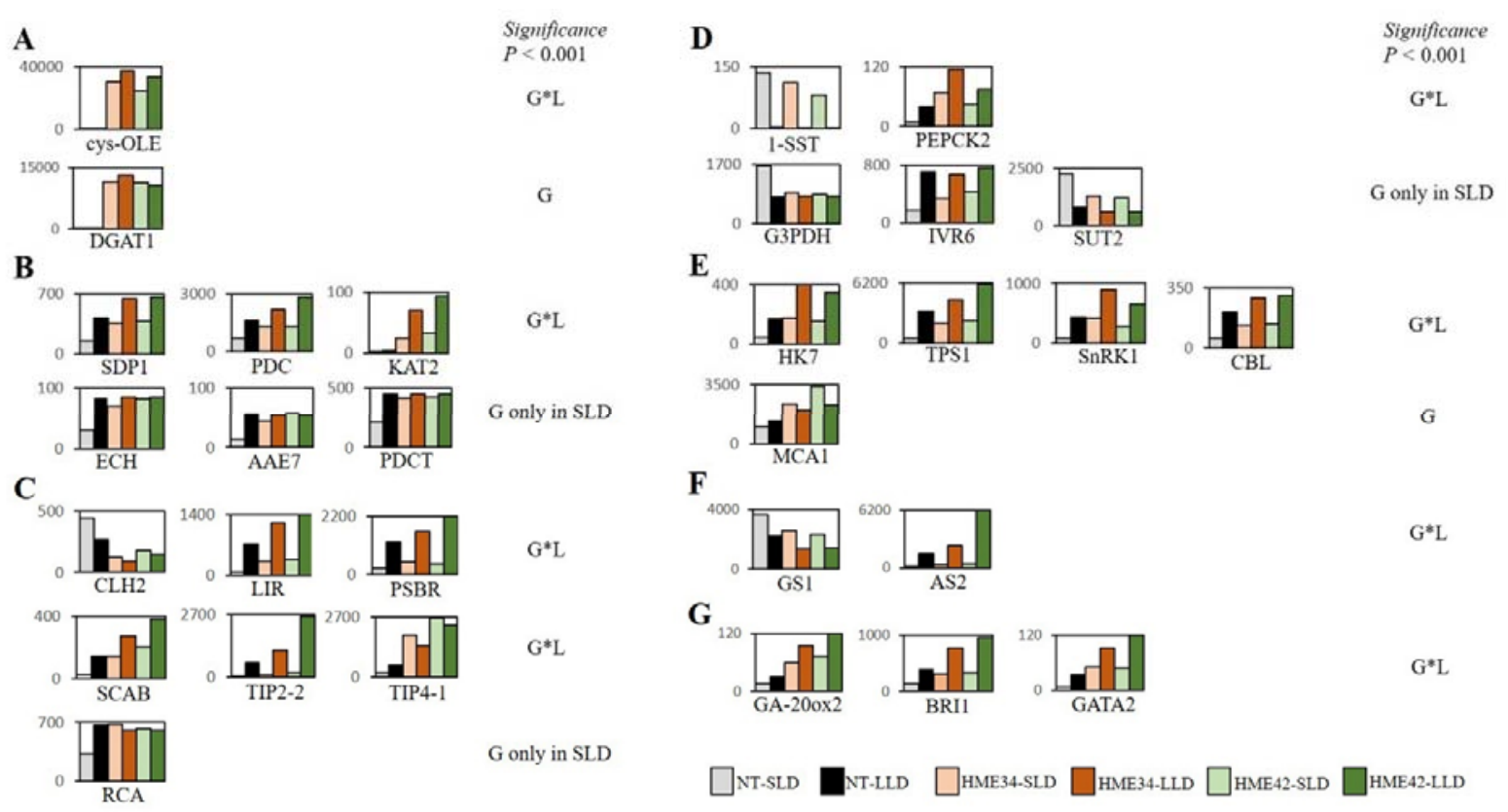

Figure 4. Normalized transcript read counts of annotated genes involving lipid (A and B), light and photosynthesis (C), carbohydrate (D), sugar and oxidative stress signalling (E), nitrogen assimilation (F), and plant growth and development pathways (G) showed differential expression between high metabolizable energy (HME) and non-transformed (NT) ryegrass grown under standard light density (SLD) and low light density 724 (LLD). Each data point represented an average from 3 biological replicates statistically analysed with significance $P<0.001$ between genotype $725(\mathrm{G})$, genotype times light interaction $\left(\mathrm{G}^{*} \mathrm{~L}\right)$, and $\mathrm{G}$ only in SLD. 
bioRxiv preprint doi: https://doi.org/10.1101/2021.05.09.443314; this version posted May 10, 2021. The copyright holder for this preprint (which

was not certified by peer review) is the author/funder, who has granted bioRxiv a license to display the preprint in perpetuity. It is made available under aCC-BY-NC-ND 4.0 International license.

726

727

728

729

730

731

732

733

734

735

736

737

738

739

740

741

742

743

744

745

746

747

748

749

750

751

752

753

754

755

756

757

758

759

760

761

762

763

Gene abbreviation included cys-OLE = cysteine-oleosin; DGAT1 = diacylglycerol acyltransferase 1; SDP1 = triacylglycerol lipase sugar-dependent 1; PDC = pyruvate dehydrogenase E1 complex; KAT2 = peroxisomal 3ketoacyl-CoA thiolase 2; ECH = peroxisomal enoyl-CoA hydratase 1; AAE7 = peroxisomal acetate/butyrateCoA ligase; $P D C T=$ phosphatidylcholine:diacylglycerol choline phosphatase; $C L H 2=$ chloroplastic chlorophyllase 2; LIR = chloroplastic light-regulated protein; PSBR = photosystem II $10 \mathrm{kDa}$ proteins; SCAB = stomatal closure-related actin-binding protein; TIP2-2\&4-1 = aquaporin tonoplast intrinsic proteins 2-2\&41; $R C A=$ ribulose bisphosphate carboxylase/oxygenase activase; 1-SST = sucrose-sucrose 1fructosyltransferase; PEPCK2 = phosphoenolpyruvate carboxylate kinase 2; G3PDH = glyceraldehyde 3phosphate dehydrogenase; IVR6 = $\beta$-fructofuranosidase (insoluble invertase) 6 ; SUT2 = sucrose transport protein 2; HK7 = hexokinase 7; TPS1 = trehalose 6-phosphate synthase 1; SnRK1 = sugar non-fermented 1 related protein kinase; $C B L=$ calcineurin B-like protein 3; $M C A 1=$ metacaspase 1; GS1 = cytosolic glutamine synthetase 1; AS2 = asparagine synthetase 2 (glutamine-hydrolyzing); GA-20ox2 = gibberellin 20 oxidase 2; $B R I 1=$ brassinosteroid LRR receptor kinase; GATA2 = G-type light-responsive element transcription factor.

(1)

2

4

5

47

8

9

0

1

2

53



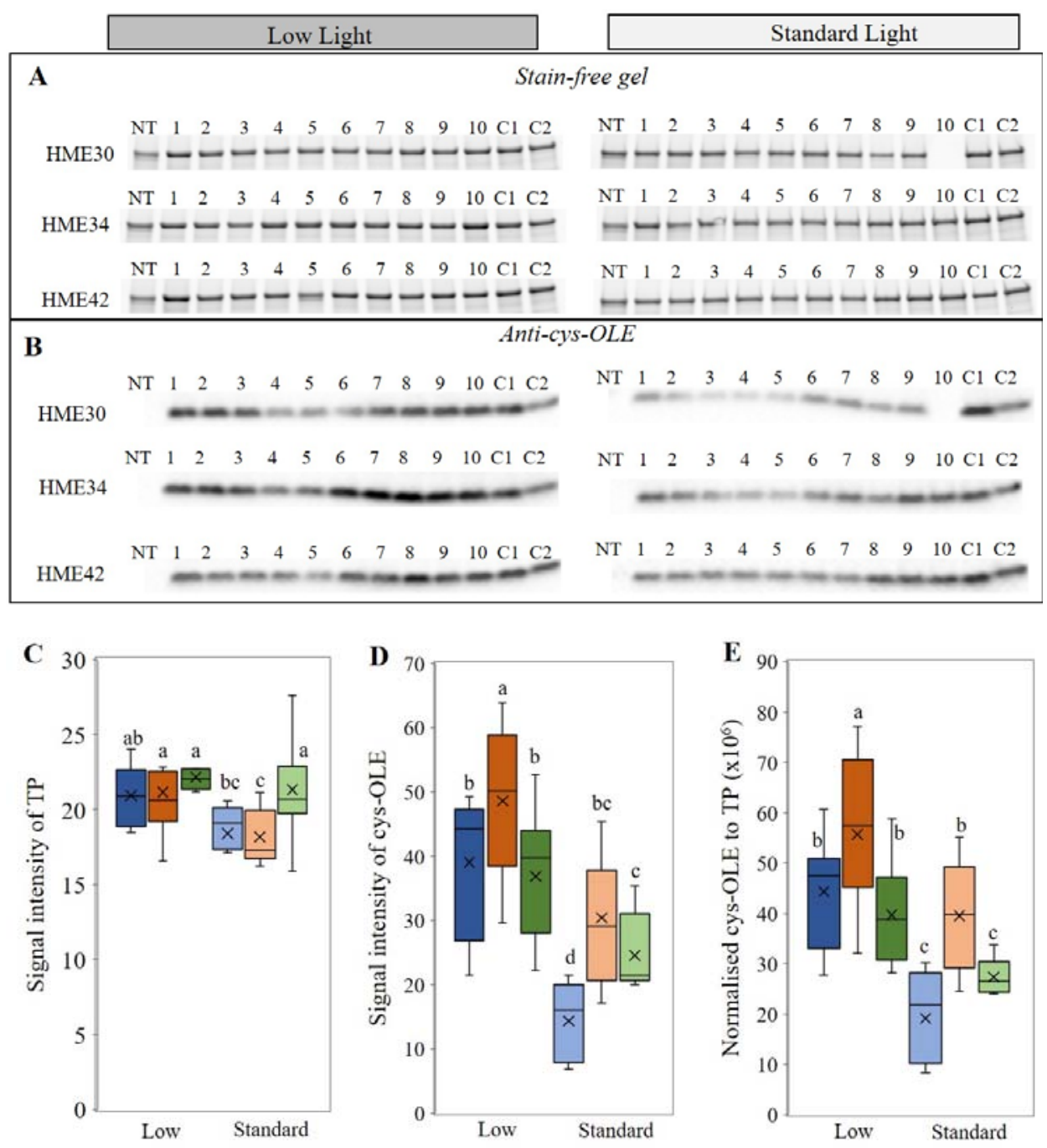

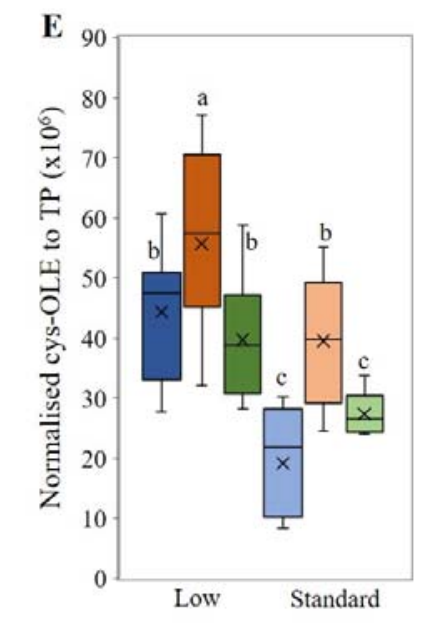

Growth irradiance

$\square$ HME30 $\square \square$ HME34 $\square \square$ HME42

Supplementary Figure S1. Determination of cysteine-oleosin (cys-OLE) accumulation in leaves of high metabolizable energy (HME) ryegrass and non-transformed plants (NT) grown under low and standard lights. Stain-free gel analysis (A) of total proteins extracted from 25 mg of leaf dry material (images showed $\sim 56 \mathrm{kDa}$ band intensity), and (B) immunoblotting results using anti-oleosin antibody; $\mathrm{C} 1$ and $\mathrm{C} 2$ were controls of protein loading and immunoblotting. (C) Box and Whisker plots of signal intensity of total proteins, (D) cysOLE and (E) normalised signal intensity of cys-OLE to total proteins (TP). ${ }^{\mathrm{a}-\mathrm{d}}$ Alphabets indicated statistical difference $(P<0.05) . \mathrm{df}=53$. 
bioRxiv preprint doi: https://doi.org/10.1101/2021.05.09.443314; this version posted May 10, 2021. The copyright holder for this preprint (which was not certified by peer review) is the author/funder, who has granted bioRxiv a license to display the preprint in perpetuity. It is made available under aCC-BY-NC-ND 4.0 International license.

782 


\section{Parsed Citations}

Aguilera-Alvarado GP, Sánchez-Nieto S (2017) Plant hexokinases are multifaceted proteins. Plant Cell Physiol 58: 1151-1160

Google Scholar: Author Only Title Only Author and Title

Andrews M, Morton J, Lieffering M, Bisset L (1992) The partitioning of nitrate assimilation between root and shoot of a range of temperate cereals and pasture grasses. Ann Bot 70: 271-276

Google Scholar: Author Only Title Only Author and Title

Asada K (2006) Production and scavenging of reactive oxygen species in chloroplasts and their functions. Plant Physiol 141: $391-396$ Google Scholar: Author Only Title Only Author and Title

Baena-González E, Rolland F, Thevelein JM, Sheen J (2007) Acentral integrator of transcription networks in plant stress and energy signalling. Nature 448: 938-942

Google Scholar: Author Only Title Only Author and Title

Bao X, Focke M, Pollard M, Ohlrogge $J(2000)$ Understanding in vivo carbon precursor supply for fatty acid synthesis in leaf tissue. Plant J 22: 39-50

Google Scholar: Author Only Title Only Author and Title

Beechey-Gradwell Z, Cooney L, Winichayakul S, Andrews M, Hea SY, Crowther T, Roberts N (2020) Storing carbon in leaf lipid sinks enhances perennial ryegrass carbon capture especially under high $\mathrm{N}$ and elevated CO2. J Exp Bot 71: 2351-2361

Google Scholar: Author Only Title Only Author and Title

Beechey-Gradwell $\mathbb{Z}$, Winichayakul S, Roberts NJ (2018) High lipid perennial ryegrass growth under variable nitrogen, water and carbon dioxide supply. Proc NZ GrassI Assoc 80: 49-54

Google Scholar: Author Only Title Only Author and Title

Benjamini Y, Hochberg Y (1995) Controlling the false discovery rate: a practical and powerful approach to multiple testing. J R Stat Soc Series B Stat Methodol 57: 289-300

Google Scholar: Author Only Title Only Author and Title

Bernard SM, Moller ALB, Dionisio G, Kichey T, Jahn TP, Dubois F, Baudo M, Lopes MS, Tercé-Laforgue T, Foyer CH, Parry MA, Forde BG, Araus JL, Hirel B, Schjoerring JK, Habash DZ (2008) Gene expression, cellular localisation and function of glutamine synthetase isozymes in wheat (Triticum aestivum L.). Plant Mol Biol 67: 89-105

Google Scholar: Author Only Title Only Author and Title

Bhaduri S, Singh SK, Cohn W, Hasan SS, Whitelegge JP, Cramer WA(2020) Anovel chloroplast super-complex consisting of the ATP synthase and photosystem I reaction center. PLoS One 15(8): e0237569

Google Scholar: Author Only Title Only Author and Title

Bienert GP, Chaumont F (2014) Aquaporin-facilitated transmembrane diffusion of hydrogen peroxide. Biochim Biophys Acta 1840: 15961604

Google Scholar: Author Only Title Only Author and Title

Browse J, McCourt PJ, Somerville CR (1986) Fatty acid composition of leaf lipids determined after combined digestion and fatty acid methyl ester formation from fresh tissue. Anal Biochem 152: 141-145

Google Scholar: Author Only Title Only Author and Title

Černý M, Habánová H, Berka M, Luklová M, Brzobohatý B (2018) Hydrogen peroxide: its role in plant biology and crosstalk with signalling networks. Int J Mol Sci 19: 2812-2841

Google Scholar: Author Only Title Only Author and Title

Cho YH, Hong JW, Kim EC, Yoo SD (2012) Regulatory functions of SnRK1 in stress-responsive gene expression and in plant growth and development. Plant Physiol 158: 1955-1964

Google Scholar: Author Only Title Only Author and Title

Chory J, Susek R (1994) Light signal transduction and the control of seedling development in Arabidopsis. Meyerowitz E, Somerville C, eds, Cold Spring Harbour Laboratory Press, 579-614

Google Scholar: Author Only Title Only Author and Title

Coll NS, Vercammen D, Smidler A, Clover C, Van Breusegem F, Dangl JL, Epple P (2010) Arabidopsis type I metacaspases control cell death. Science 330: 1393-1397

Google Scholar: Author Only Title Only Author and Title

Cooney L, Beechey-Gradwell Z, Winichayakul S, Richardson R, Crowther T, Anderson P, Scott RW, Bryan G, Roberts N (2021) Changes in leaf-level nitrogen partitioning and mesophyll conductance deliver increased photosynthesis for Lolium perenne leaves engineered to accumulate lipid carbon sinks. Front Plant Sci 12: Article 641822

Google Scholar: Author Only Title Only Author and Title

Drerup, MM, Schlücking K, Hashimoto K, Manishankar P, Steinhorst L, Kuchitsu K, Kudla J (2013) The Calcineurin B-like calcium sensors CBL1 and CBL9 together with their interacting protein kinase CIPK26 regulate the Arabidopsis NADPH oxidase RBOHF. Mol Plant 6: 559-569 
bioRxiv preprint doi: https://doi.org/10.1101/2021.05.09.443314; this version posted May 10, 2021. The copyright holder for this preprint (which was not certified by peer review) is the author/funder, who has granted bioRxiv a license to display the preprint in perpetuity. It is made

Google Scholar: Author Only Title Only Author and Title available under aCC-BY-NC-ND 4.0 International license.

Fan J, Yan R, Roston J, Shankin C, Xu C (2014) and SDP1 triacylglycerol lipase synergistically direct fatty acid towards $\beta$-oxidation, thereby maintaining lipid homeostasis. Plant Cell 26: 4119-4134

Google Scholar: Author Only Title Only Author and Title

Feng CM, Qiu Y, Van Buskirk EK, Yang EJ, Chen M (2014) Light-regulated gene repositioning in Arabidopsis. Nature Communications 5: 3027

Google Scholar: Author Only Title Only Author and Title

Faurie O, Soussana JF, Sinoquet H (1996) Radiation interception, partitioning and use in grass-cover mixtures. Ann Bot 77 : $35-45$

Google Scholar: Author Only Title Only Author and Title

Fischer BU, Frehner M, Hebeisen T, Zanetti S, Stadelmann ., Lüscher A, Hartwig UA, Hendrey GR, Nösberger J (1997) Source-sink relations in Lolium perenne $L$. as reflected by carbohydrate concentrations in leaves and pseudo-stems during regrowth in a free air carbon dioxide enrichment (FACE) experiment. Plant Cell Environ 20: 945-952

Google Scholar: Author Only Title Only Author and Title

Foyer CH, Noctor G (2011) Ascorbate and glutathione: the heart of the redox hub. Plant Physiol 155: 2-18

Google Scholar: Author Only Title Only Author and Title

Fuhrmann E, Gathmann S, Rupprecht ED, Golecki J, Schneider D (2009) Thylakoid membrane reduction affects the photosystem stoichiometry in the Cyanobacterium Synechocystis sp. PCC 6803. Plant Physiol 149: 735-744

Google Scholar: Author Only Title Only Author and Title

Gaba V, Black M (1983) The control of cell growth by light. Photomorphogenesis, Encyclopedia of Plant Physiol, New Series, Vol. 16A Springer-Verlag, Berlin, Heidelberg, New York, Tokyo, 358-400

Google Scholar: Author Only Title Only Author and Title

García-Martinez JL, Gil J (2002) Light regulation of gibberellin biosynthesis and mode of action. J Plant Growth Regul 20: $354-368$ Google Scholar: Author Only Title Only Author and Title

Hamblin J, Stefanova K, Angessa TT (2014) Variation in chlorophyll content per unit leaf area in spring wheat and implications of selection in segregating material. PLoS One 9: e92529

Google Scholar: Author Only Title Only Author and Title

Hirel B, Bertin P, Quilleré I, Bourdoncle W, Attagnant C, Dellay C, Gouy A, Cadiou S, Retailliau C, Falque M, Gallais A(2001) Towards a better understanding of the genetic and physiological basis for nitrogen use efficiency in maize. Plant Physiol 125: 1258-1270

Google Scholar: Author Only Title Only Author and Title

Höglind M, Hanslin HM, Mortensen L (2011) Photosynthesis of Lolium perenne L. at low temperatures under low irradiances. Environ Exp Bot 70: 297-304

Google Scholar: Author Only Title Only Author and Title

Irving DE, Shingleton GJ, Hurst PL, (2001) Expression of asparagine synthetase in response to carbohydrate supply in model callus cultures and shoot tips of asparagus (Asparagus officinalis L.) J Plant Physiol 158: 561-568

Google Scholar: Author Only Title Only Author and Title

Jermyn MA(1975) Increasing the sensitivity of the anthrone method for carbohydrate. Anal Biochem 68: $332-335$

Google Scholar: Author Only Title Only Author and Title

Jiang T, Zhang Z-F, Wang X-F, Zhang DP (2011) Arabidopsis 3-ketoacyl-CoAthiolase-2 (KAT2), an enzyme of fatty acid $\beta$-oxidation, is involved in ABA signal transduction. Plant Cell Physiol 52: 528-538

Google Scholar: Author Only Title Only Author and Title

Kanehisa M, Goto S (2000) KEGG: Kyoto encyclopedia of genes and genomes. Nucleic Acids Res 28: 27-30

Google Scholar: Author Only Title Only Author and Title

Ke J, Behal RH, Back SL, Nikolau BJ, Wurtele ES, Oliver DJ (2000) The role of pyruvate dehydrogenase and acetyl-Coenzyme A synthetase in fatty acid synthesis in developing Arabidopsis seeds. Plant Physiol 123: 497-508

Google Scholar: Author Only Title Only Author and Title

Kelly AA, van Erp H, Quettier AL, Shaw E, Menard G, Kurup S, Eastmond PJ (2013) The sugar-dependent1 lipase limits triacylglycerol accumulation in vegetative tissues of Arabidopsis. Plant Physiol 162: 1282-1289

Google Scholar: Author Only Title Only Author and Title

Kim HB, Cho JI, Ryoo N, Shin DH, Park YI, Hwang YS, Lee S-K, An G, Jeon J-S (2016) Role of rice cytosolic hexokinase OsHXK7 in sugar signalling and metabolism. J Integr Plant Biol 58: 127-135

Google Scholar: Author Only Title Only Author and Title

Lee RE, Brunette S, Puente LG, Megeney LA(2010) Metacaspase Yca1 is required for clearance of insoluble protein aggregates. Proc Natl Acad Sci USA 107: 13348-13353

Google Scholar: Author Only Title Only Author and Title 
bioRxiv preprint doi: https://doi.org/10.1101/2021.05.09.443314; this version posted May 10, 2021. The copyright holder for this preprint (which was not certified by peer review) is the author/funder, who has granted bioRxiv a license to display the preprint in perpetuity. It is made

Leong T-Y, Anderson JM (1984) Adaptation of the thylakoid membranes of pea chloroplasts to light intensities. I. Study on the distribution of chlorophyll-protein complexes. Photo Res 5: 105-115

Google Scholar: Author Only Title Only Author and Title

Li L, Sheen J (2016) Dynamic and diverse sugar signalling. Curr Opin Plant Biol 33: 166-125

Google Scholar: Author Only Title Only Author and Title

Lichtenthaler H, Buschmann C, Döll M, Fietz HJ, Bach T, Kozel U, Meuer D, Rahmsdorf U (1981) Photosynthetic activity, chloroplast ultrastructure, and leaf characteristics of high-light and low-light plants of sun and shade leaves. Photosynth Res 2: 115-141

Google Scholar: Author Only Title Only Author and Title

Liu Q-H, Wu X, Chen B-C, MA J-Q, GAO J (2014) Effect of low light on agronomic and physiological characteristics of rice including grain yield and quality. Rice Sci $21: 243-251$

Google Scholar: Author Only Title Only Author and Title

Luo X-M, Lin W-H, Zhu SZ, Zhu J-Y, Sun Y, Fan X-Y, Cheng M, Hao Y, Oh E, Tian M, Liu L, Zhang M, Xie Q, Chong K, Wang Z-Y (2010) Integration of light- and brassinosteroid-signaling pathways by a GATA transcription factor in Arabidopsis. Dev Cell 19: $872-883$

Google Scholar: Author Only Title Only Author and Title

Lu T, Yu H, Li Q, Chai L, Jiang W(2019) Improving plant growth and alleviating photosynthetic inhibition and oxidase stress from lowlight stress with exogenous GR24 in tomato (Solanum lycopersicum L.) seedlings. Front Plant Sci 10: 490

Google Scholar: Author Only Title Only Author and Title

Maurel C, Boursiac Y, Luu D-T, Santoni V, Shahzad Z, Verdoucq L (2015) Aquaporins in plants. Physiol Rev 95: 1321-1358

Google Scholar: Author Only Title Only Author and Title

McClain AM, Sharkey TD (2019) Triose phosphate utilization and beyond: from photosynthesis to end product synthesis. J Exp Bot 70 : 1755-1766

Google Scholar: Author Only Title Only Author and Title

Melis A(1984) Light regulation of photosynthetic membrane structure, organization, and function. J Cell Biochem 24: 271-285

Google Scholar: Author Only Title Only Author and Title

Miazek K, Ledakowicz S (2013) Chlorophyll extraction from leaves, needles and microalgae: Akinetic approach. Int J Agric Biol Eng 6: 107-115

Google Scholar: Author Only Title Only Author and Title

Mitchell MC, Pritchard J, Okada J, Zhang J, Venables I, Vanhercke T, Ral J-P (2020) Increasing growth and yield by altering carbon metabolism in a transgenic leaf oil crop. Plant Biotechnol J 18: 2042-2052

Google Scholar: Author Only Title Only Author and Title

Mukherjee S, Stasolla C, Brule-Babel A, Ayele BT (2015) Isolation and characterization of rubisco small subunit gene promoter from common wheat (Triticum aestivum L.). Plant Signal Behav 10: 2, e989033.

Google Scholar: Author Only Title Only Author and Title

Mulo P (2011) Chloroplast-targeted ferredoxin-NADP+ oxidoreductase (FNR): Structure, function and location. Biochim Biophys Acta 1807: $927-934$

Google Scholar: Author Only Title Only Author and Title

Niu L, Liao W (2016) Hydrogen peroxide signalling in plant development and abiotic responses: Crosstalk with nitric oxide and calcium Front Plant Sci 7: 230

Google Scholar: Author Only Title Only Author and Title

Obara M, Sato T, Sasaki S, Kashiba K, Nagano A, Nakamura I, Ebitani T, Yano M, Yamaya T (2004) Identification and characterization of a QTL on chromosome 2 for cytosolic glutamine synthetase content and panicle number in rice. Theor Appl Genet 110: 1-11

Google Scholar: Author Only Title Only Author and Title

Oszvald M, Primavesi LF, Griffiths CA, Cohn J, Basu SS, Nuccio ML, Paul MJ (2018) Trehalose 6-phospahte regulates photosynthesis and assimilate portioning in reproductive tissue. Plant Physiol 176: 2623-2638

Google Scholar: Author Only Title Only Author and Title

Paul MJ, Eastmond PJ (2020) Turning sugar into oil: making photosynthesis blind to feedback inhibition. J Exp Bot 71: $2216-2218$

Google Scholar: Author Only Title Only Author and Title

Paul MJ, Foyer CH (2001) Sink regulation of photosynthesis. J Exp Bot 52: 1383-1400

Google Scholar: Author Only Title Only Author and Title

Pellny TK, Ghannoum O, Conroy JP, Schluepmann H, Smeekens S, Andralojc J, Krause KP, Goddijn O, Paul M (2004) Genetic modification of photosynthesis with E. coli genes for trehalose synthesis. Plant Biotechnol J 2: 71-82

Google Scholar: Author Only Title Only Author and Title

Perdomo JA Capó-Bauçà S, CArmo-Silva E, Galmés J (2017) Rubisco and Rubisco activase play an important role in the biochemical limitations of photosynthesis in rice, wheat, and maize under high temperature and water deficit. Front Plant Sci 8: 490

Google Scholar: Author Only Title Only Author and Title 
bioRxiv preprint doi: https://doi.org/10.1101/2021.05.09.443314; this version posted May 10, 2021. The copyright holder for this preprint (which was not certified by peer review) is the author/funder, who has granted bioRxiv a license to display the preprint in perpetuity. It is made available under aCC-BY-NC-ND 4.0 International license.

Pollock CJ, Cairns AJ (1991) Fructan metabolism in grasses and cereals. Ann Rev Plant Physiol Plant Mol Biol 42: 77-101

Google Scholar: Author Only Title Only Author and Title

Praba ML, Vanangamudi M, Thandapani V (2011) Effects of low light on yield and physiological attributes of rice. International Rice Research Notes 29.

Google Scholar: Author Only Title Only Author and Title

Queval G, Foyer C (2012) Redox regulation of photosynthetic gene expression. Philos Trans R Soc Lond, B, Biol Sci 367: $3475-3485$

Google Scholar: Author Only Title Only Author and Title

Roberts NJ, Scott RW, Winichayakul S, Roldan M (2010) Modified neutral lipid encapsulating proteins and uses thereof.

PCT/NZ2010/000218 WO/2011/053169

Google Scholar: Author Only Title Only Author and Title

Roberts NJ, Scott RW, Winichayakul S, Roldan M (2011) Methods for increasing CO2 assimilation and oil production in photosynthetic organisms. WO2013022053A1, US61/515,610

Google Scholar: Author Only Title Only Author and Title

Rolland F, Moore B, Sheen J (2002) Sugar sensing and signalling in plants. Plant Cell S185-S205

Google Scholar: Author Only Title Only Author and Title

Sanjaya, Durrett TP, Weise SE, Benning C (2011) Increasing the energy density of vegetative tissues by diverting carbon from starch to oil biosynthesis in transgenic Arabidopsis. Plant Biotechnol J 9: 874-883

Google Scholar: Author Only Title Only Author and Title

Silvente S, Reddy PM, Khandual S, Blanco L, Alvarado-Affantranger X, Sanchez F, and Lara-Flores M (2008) Evidence for sugar signalling in the regulation of asparagine synthetase gene expressed in Phaseolus vulgaris roots and nodules. J Exp Bot 59: 12791294

Google Scholar: Author Only Title Only Author and Title

Steinhorst L, Kudla J (2013) Calcium and reactive oxygen species rule the waves of signaling. Plant Physiol 163: 471-485

Google Scholar: Author Only Title Only Author and Title

Tsai AY-L, Gazzarrini S (2014) Trehalose-6-phosphate and SnRK1 kinases in plant development and signalling: the emerging picture. Front Plant Sci 5: 1-11

Google Scholar: Author Only Title Only Author and Title

Tsiatsiani L, van Breusegem F, Gallois P, Zavialov A, Lam E, Bozhkov PV (2011) Metacaspases. Cell Death Differ 18: $1279-1288$ Google Scholar: Author Only Title Only Author and Title

Vanhercke T, Divi UK, El Tahchy A, Liu Q, Mitchell M, Taylor MC, Eastmond PJ, Bryant F, Mechanicos A, Blundell C, Zhi Y, Belide S, Shrestha P, Zhou X-R, Ral J-P, White RG, Green A Singh SP, Petrie JR (2017) Step changes in leaf oil accumulation via iterative metabolic engineering. Metab Eng 39: 237-246

Google Scholar: Author Only Title Only Author and Title

Vanhercke T, Dyer JM, Mullen RT, Kilaru A, Mahbubur Rahman Md, Petrie JR, Green AG, Yuchenko O, Singh SR (2019) Metabolic engineering for enhance oil in biomass. Prog Lipid Res 74: 103-129

Google Scholar: Author Only Title Only Author and Title

Vercammen, D, van de Cotte B, De Jaeger G, Eeckhout D, Casteels P, Vandepoele K, Vandenberghe I, van Beeumen J, Inzé D, and van Breusegem F (2004) Type II metacaspases Atmc4 and Atmc9 of Arabidopsis thaliana cleave substrates after arginine and lysine. J Biol Chem 279: 45329-45336

Google Scholar: Author Only Title Only Author and Title

Warren CR (2008) Rapid measurement of chlorophylls with a microplate reader. J Plant Nutr 31: 1321-1332

Google Scholar: Author Only Title Only Author and Title

Winichayakul S, Beechy-Gradwell Z, Muetzel S, Molano G, Crowther T, Lewis S, Xue H, Burke J, Bryan G, Roberts, NJ (2020) In vitro gas production and rumen fermentation profile of fresh and ensiled genetically modified high-metabolizable energy ryegrass. $\mathrm{J}$ Dairy Sci 103: 2405-2418

Google Scholar: Author Only Title Only Author and Title

Winichayakul S, Moyle R, Ryan DJ, Farnden KJF, Davies KM, Coupe SA(2004) Distinct cis-elements in the Asparagus officinalis asparagine synthetase promoter respond to carbohydrate and senescence signals. Funct Plant Blol 31: 573-582

Google Scholar: Author Only Title Only Author and Title

Winichayakul S, Scott WR, Roldan M, Hatier JHB, Livingston S, Cookson R, Curran AC, Roberts NJ (2013) In vivo packaging of triacylglycerols enhances Arabidopsis leaf biomass and energy density. Plant Physiol 162: 626-639

Google Scholar: Author Only Title Only Author and Title

Wang C, Zheng Y, Zhao Y, Zhao Y, Li J, Guo Y (2015) SCAB3 is required for reorganization of actin filaments during light quality changes. J Genet Genomics 42: 161-168

Google Scholar: Author Only Title Only Author and Title 
bioRxiv preprint doi: https://doi.org/10.1101/2021.05.09.443314; this version posted May 10, 2021. The copyright holder for this preprint (which was not certified by peer review) is the author/funder, who has granted bioRxiv a license to display the preprint in perpetuity. It is made available under aCC-BY-NC-ND 4.0 International license.

Wurzinger B, Nukarinen E, Nägele T, Weckwerth W,a,b Teige M (2018) The SnRK1 kinase as central mediator of energy signaling between different organelles. Plant Physiol 176: 1085-1094

Google Scholar: Author Only Title Only Author and Title

Xu C, Shanklin J (2016) Triacylglycerol metabolism, function, and accumulation in plant vegetative tissues. Ann Rev Plant Biol 67: 179206

Google Scholar: Author Only Title Only Author and Title

Yu L, Fan J, Zhou C, Xu C (2021) Chloroplast lipid biosynthesis is fine-tuned to thylakoid remodelling during light acclimation. Plant Physiol 185: 94-107

Google Scholar: Author Only Title Only Author and Title

Zhao Y, Zhao S, Mao T, Qu X, Cao W, Zhang L, Guo Y (2011) The plant-specific actin binding protein SCAB1 stabilizes actin filaments and regulates stomatal movement in Arabidopsis. Plant Cell 23: 2314-2330

Google Scholar: Author Only Title Only Author and Title

Zhu H, Li X, Zhai W, Liu Y, Gao Q, Liu J, Ren L, Chen H, Zhu Y (2017) Effects of low light on photosynthetic properties, antioxidant enzyme activity, and anthocyanin accumulation in purple pak-choi (Brassica campestris ssp. Chinensis Makino). PLos One 12: e0179305

Google Scholar: Author Only Title Only Author and Title 